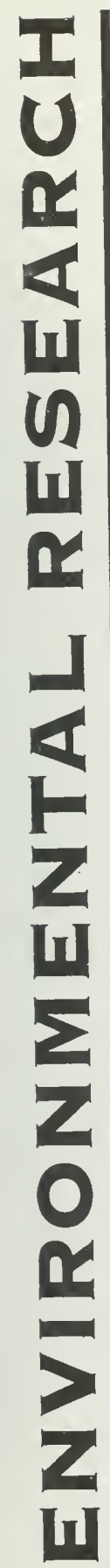

MICROBIOLOGICAL INDICATORS FOR ASSESSING

HYDRAULIC CONNECTION IN

BURIED HIGH PERMEABILITY ZONES

AT WASTE DISPOSAL SITES - FINAL REPORT

RAC Project No. 543G

MINISTRY OF ENVIRONMENT AND ENERGY

(9) Ontario 



\section{MICROBIOLOGICAL INDICATORS FOR ASSESSING HYDRAULIC CONNECTION IN \\ BURIED HIGH PERMEABILITY ZONES \\ AT WASTE DISPOSAL SITES - FINAL REPORT \\ RAC Project No. 543G}

\section{FEBRUARY 1996}

\section{5}

Cette publication technique n'est disponible qu'en anglais. Copyright: Queen's Printer for Ontario, 1996

This publication may be reproduced for non-commercial purposes with appropriate attribution.

PIBS 3421E 

MICROBIOLOGICAL INDICATORS FOR ASSESSING

HYDRAULIC CONNECTION IN

BURIED HIGH PERMEABILITY ZONES

AT WASTE DISPOSAL SITES

FINAL REPORT

RAC Project No. 543G

Report prepared by:

Maxine Holder-Franklin, PhD

Department of Biological Sciences

University of Windsor, Windsor, Ontario

In collaboration with:

Essex Windsor Solid Waste Management Authority Essex, Ontario

Jagger Hims Consulting Engineers

Newmarket, Ontario

Michael Sklash, PhD

Department of Geology

University of Windsor, Windsor, Ontario

and

Dragun Corporation

Novi, Michigan, U.S.A. 



\section{ACKNOWLEDGEMENT AND DISCLAIMER}

This report was prepared for the Ontario Ministry of Environment and Energy as part of a Ministry funded project. The views expressed in this report are those of the author and do not necessarily reflect the views and policies of the Ministry of Environment and Energy, nor does mention of trade names or commercial products constitute endorsement or recommendation for use. The Ministry, however, encourages the distribution of information and strongly supports technology transfer and diffusion.

Any person who wishes to republish part or all of this report should apply for permission to do so to the Environmental Research Program, Science and Technology Branch, Ontario Ministry of Environment and Energy, 135 St. Clair Avenue West, Suite 100, Toronto, Ontario, Canada, M4V 1 P5. 



\section{Table of Contents:Section 1}

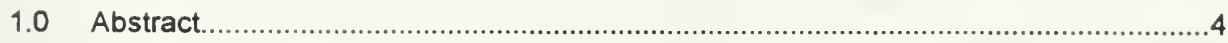

2.0 Analysis of heterotrophic microbial populations in sanitary landfills..........................7

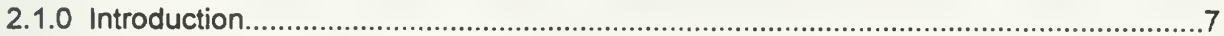

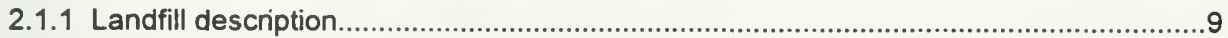

2.1.2 Microbiological Studies.................................................................................. 10

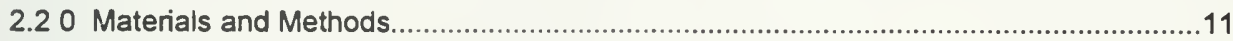

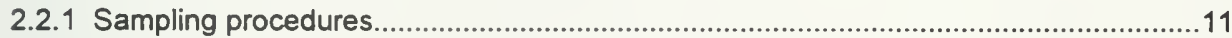

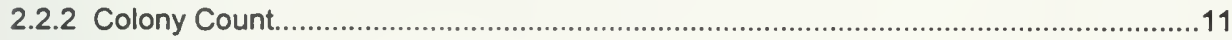

2.2.3 E.coli and Salmonella screening................................................................... 11

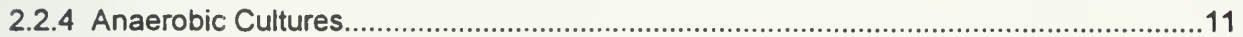

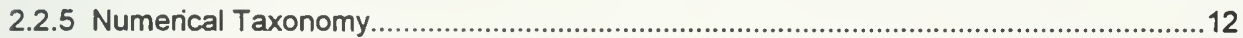

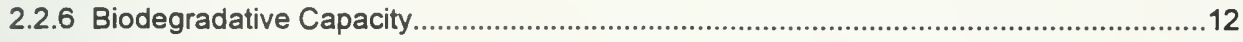

2.3.0 Results..................................................................................................... 14

2.3.1 Groundwater Chemistry .............................................................................. 14

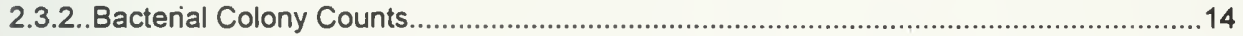

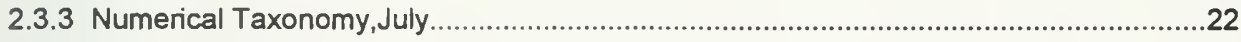

2.3.4..Numerical Taxonomy:September and October......................................................23

2.3.5..Numerical Analysis:July,September, October...................................................23

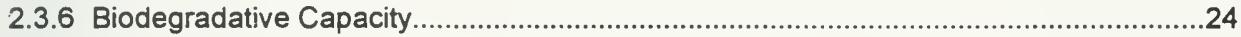

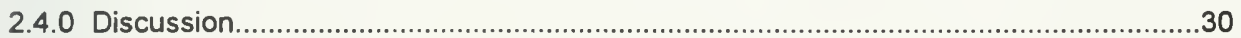

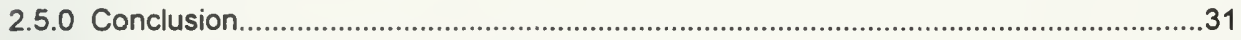

3.0 Principal Components Analysis of Bacterial Test Responses..................................32

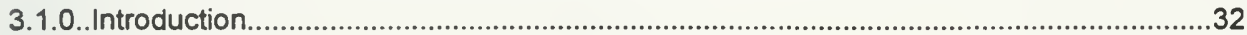

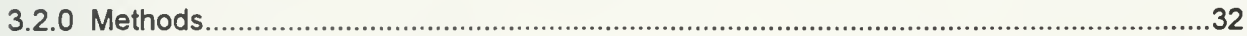

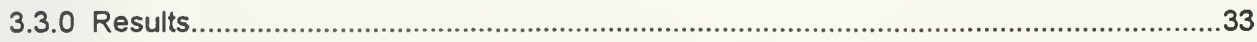

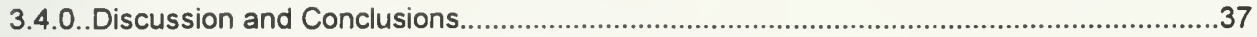

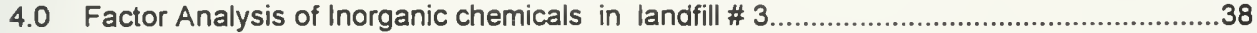

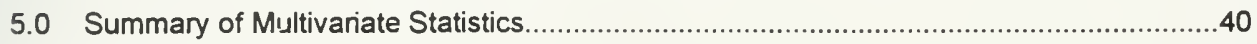

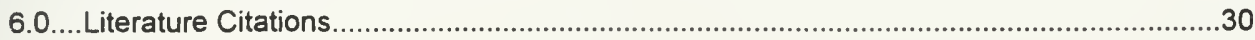


Acknowledgements:

The research presented in this report was performed by Lawrence Wuest, Bernardo Mangiola, Chantelle Bezaire, Marguerita Maravilla, Charlene Szpak and Samira Georges.

The author is very grateful for the assistance of Theresa Marentette and Todd Pepper of the Essex Windsor Solid Waste Management Authority who made the study possible.

The report graphics were assembled by lan Mclnnis and Lawrence Wuest.

Nestor Ocampo assisted in the final editing and structure of the graphics and format. 


\section{LEGENDS}

\section{Figures}

Figure 1. Map of Landfill \#3 Essex County, Ontario. 6

Figure 2. Hydrostratigraphic zones of Landfill \#3 8

Figure 3. Specific conductivity of monitor samples $\mu$ Siemens $\mathrm{mL}^{-1}$. 16

$\begin{array}{lll}\text { Figure 4. } & \mathrm{pH} \text { of monitor samples. } & 17\end{array}$

$\begin{array}{lll}\text { Figure 5. Temperature of monitor samples } & 18\end{array}$

$\begin{array}{ll}\text { Figure 6. Bacterial counts in colony forming units } \mathrm{mL}^{-1} \text {. } & 19\end{array}$

Figure 7. Cluster analysis matrix diagram of 369 strains 20

Figure 8. Categorized tests responses of isolates. Summer 27

Figure 9. Categorized tests responses of isolates. Autumn 28

Figure 10. Combined cluster analysis matrix, July, Sept.,October 29

\section{Tables}

$\begin{array}{lll}\text { Table 1. Location and age of refuse monitors. } & 10\end{array}$

Table 2. Monitor locations and Bacterial viable counts 13

Table 3. Numerical taxonomy July. Tree matrix. 21

Table 4. Mean Intergroup coefficients of July isolates 22

Table 5. Identification of clusters of Sept./ Oct.samples 25

Table 6. Tests for numerical taxonomy and identification. 26

Table 7. Mean Intergroup coefficients of 4 clusters, July,Sept.Oct. 24

Table 8. Principal components analysis of bacterial tests. 34

Table 9 Summary of bacterial factors 36

Table 10 Interpretation of factors and eigenvalues 38

Table 11 Factor matrix of inorganic chemicals 39

Table 12 Factor correlation matrix 41

Table 13 Communality of the chemical values 41 


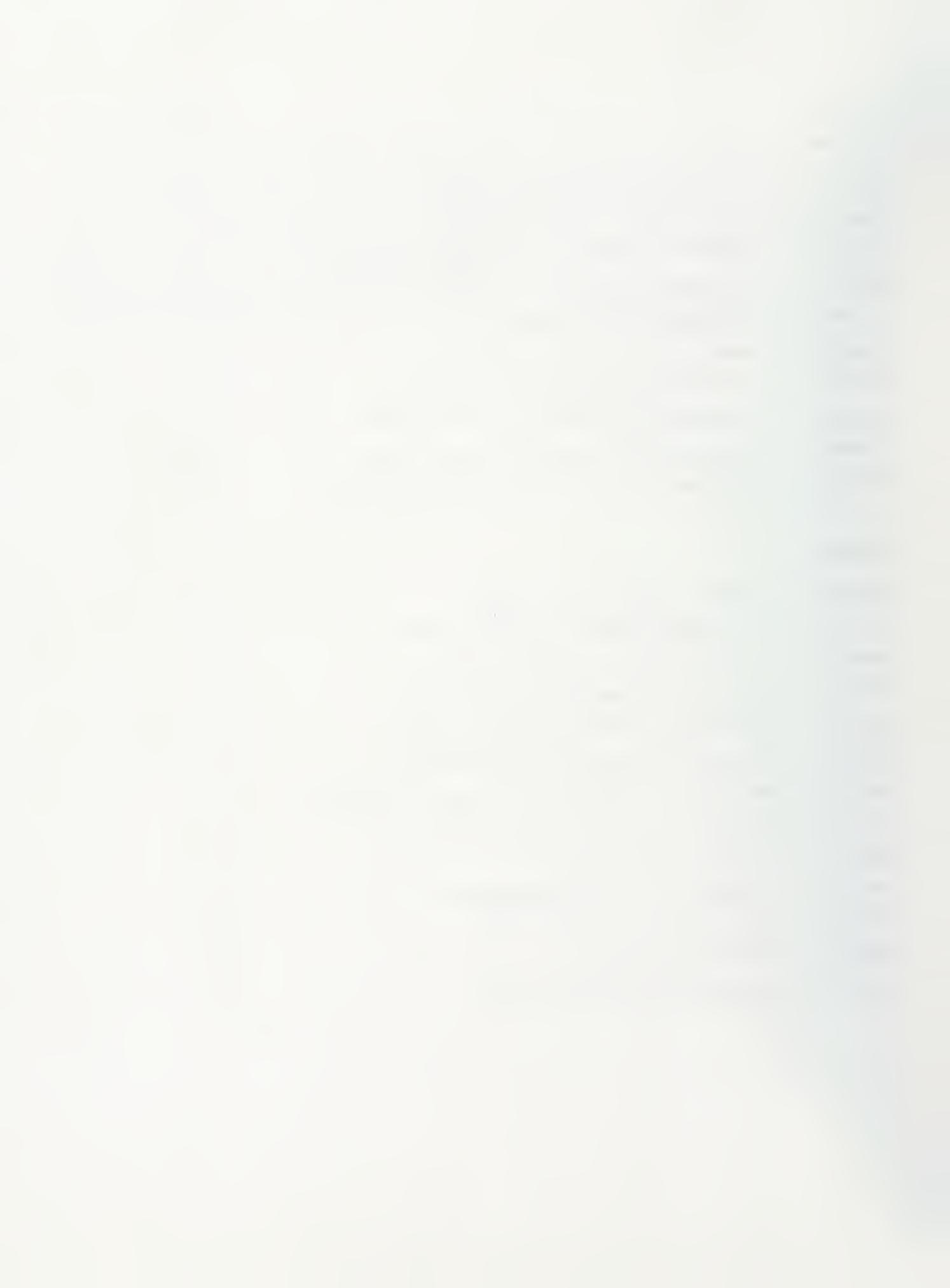




\subsection{ABSTRACT}

A combined hydrogeological and microbiological analysis of landfill leachate and soils in Essex County has been initiated to study the vertical and horizontal flow rates of ground water. The silty clay plain of Essex County was once considered to be relatively impervious to the transport of water and solutes. The discovery of discontinuous high permeability zones (HPZ) or sand lenses created some doubt about the safety of ground and surface water near waste disposal sites. This report forms the basis for a series of research findings that have been presented as workshops, and symposia and published as abstracts and a thesis. The bulk of the research centres around the Maidstone landfill \#3. As part of the geological study, well nests were drilled at several sites to determine possible impact of the landfills through the HPZ. The analysis of one of these sites which is $60 \mathrm{~m}$ from Lake St. Clair on Charron Beach has been published in two theses, one deals with the geological aspects [Ibrahim 1992] and the second relates the geological features to the microbiological findings [Georges 1995]. At this site, the isotopes ${ }^{3} \mathrm{H},{ }^{2} \mathrm{H}$, and ${ }^{18} \mathrm{O}$ were analyzed according to the methods of Sklash and Ainsley [1991]. Vertical ground water flow rates were determined by physical tests. Sub-surface studies of bacteria have revealed that viable bacteria can be found at great depths depending on the soil conditions [Balkwill 1989]. In fact below first 10 feet with the exception of some aquifers theonly biota are bacteria.

The Charron Beach ground water in the deep well of site 3 is 11,000 years old. Similarly, water from two other wells is $7,000-10,000$ years old, which is a unique finding - the use of isotopes to determine the age of bacteria. The Charron Beach results are reported in a separate document [Georges 1995, M.Sc. Thesis]

Samples were obtained from 25 wells at the landfill and the viable heterotrophic bacteria were quantitated by aerobic and anaerobic counts. The populations within each site were compared using cluster analysis of similarity coefficients obtained from a 63 character test base. In addition to the cluster analysis, the landfill data was further analysed by the computation of principal components and factors, both multivariate statistical analyses. These algorithms extract the essential variance and enable the analysis of non-parametric data, constructing a matrix which forms the basis for the comparison of a series of databases.

At the landfill, each monitor yielded a different population and these populations could be related in part to the chemical environment. Samples of landfill leachate and ground water were analyzed for $>150$ chemical and physical parameters by the consulting engineers, Jagger Hims Ltd.. The landfill leachate yielded a variety of aerobic and facultative heterotrophic bacteria which had a 
moderately active biodegradative capacity except in those refuse monitors where the concentration of sodium chloride was high enough to inhibit the metabolic activity of the organisms. Finally, Salmonella and E. coli could not be isolated from the leachate. An extensive study for the detection of E.coli and Salmonella over a three year period is presented in Report 1995, section 2. Many species of heterotrophic bacteria which are classified as secondary or potential pathogens were isolated. In conclusion, the aquitard does inhibit the movement of groundwater and bacteria through the sub-surface environment. Only one monitor a few yards away from the refuse exhibited any influence from the leachate and that monitor was also identified by the Jagger Hims report. Isotopes and bacteria are excellent indicators of groundwater movement.

The use of waste disposal facilities is based on the premise that the microbial populations will degrade the refuse over time. Sites are selected such that complete containment of the chemical and microbial contaminants will continue indefinitely or at least long enough for a partial degradation of possible hazards. The ability of the microbial consortia to digest, transform or mineralize the array of compounds in a landfill can be compromised by several environmental influences. These influences are a combination of native characteristics and the waste disposal practices. Before refuse sites can be designed, it is necessary to obtain basic information on the landfill and the bacterial populations. In reality, this information is only obtained after the fill is well established and only for the very few landfills studied microbiologically. There were many flaws in the original design and maintenance of landfill\#3. Some errors have been corrected, some problems, now predictable are continued. Historically, when the practice of covering a public dump with soil was first used, the rationale appears to have been to store waste not to provide conditions for biodegradation. Landfill \#3 has had a face lift but no measures have been taken to improve the degradation of the waste. The hazards to the surrounding area and biota have been carefully monitored but the remedial attention has been restricted to containment. 


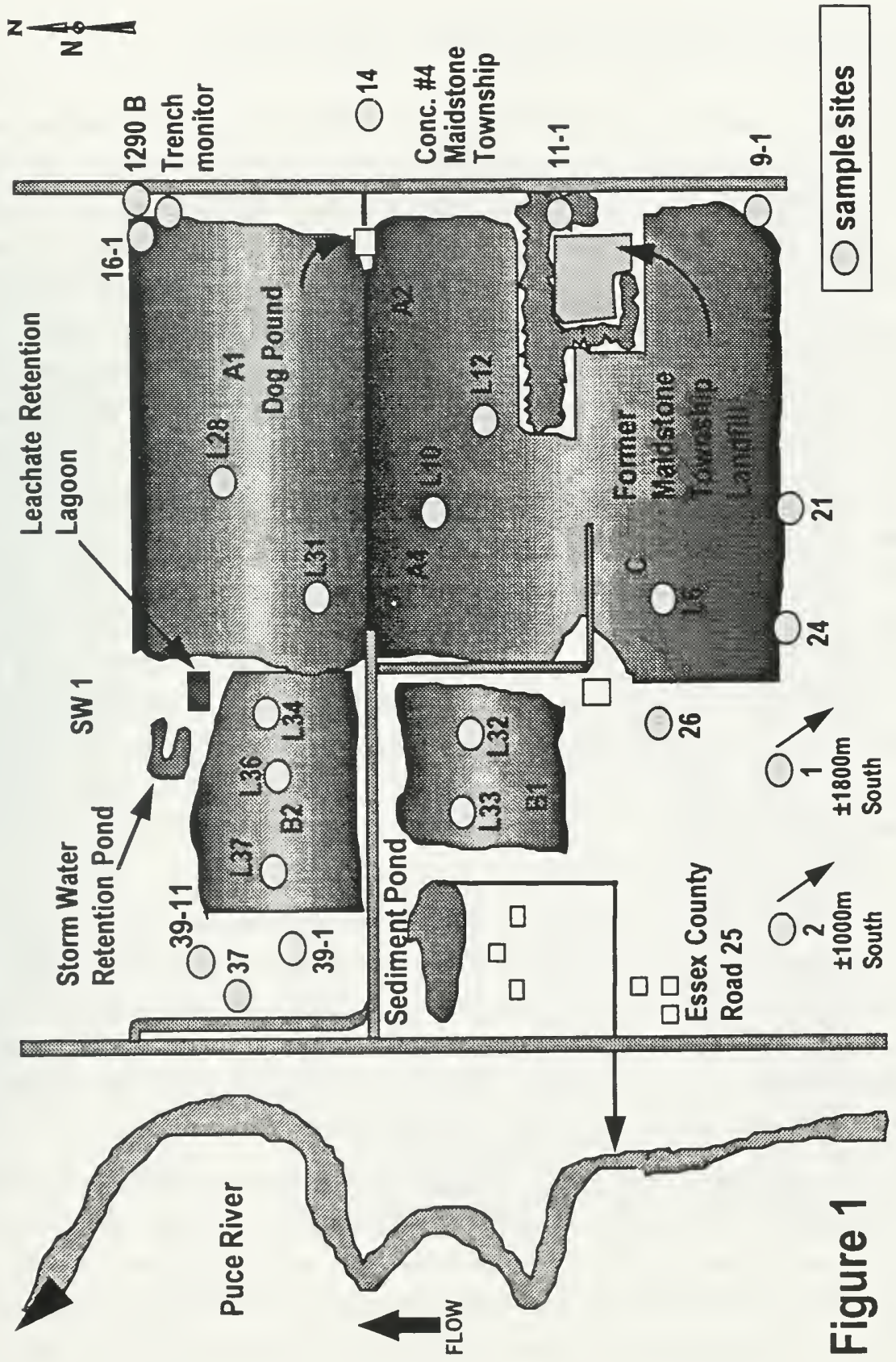




\subsection{Analysis of heterotrophic microbial populations in sanitary landfills}

\subsection{Introduction}

An ecological approach has been selected for the study of heterotrophic bacterial populations in a waste disposal facility. Two aspects of waste disposal are being addressed, the factors controlling the maintenance of a large and vigorous microbial population actively involved in biodegradation and the retention of potentially pathogenic bacteria within the drainage borders of the site. Numerical taxonomy clustering methods were used to determine the similarities or uniqueness of the various populations being sampled (Holder-Franklin, 1981). Initially, it was expected that bacterial populations could be tracked through the landfill and possibly beyond the periphery thus characterizing the bacterial hazards associated with the refuse. The study began with the characterization of the aerobic heterotrophic population, followed by the selective cultivation of human biohazards and thirdly, the possible movement of these organisms within the hydrostratigraphic zones and the surface waters. Bacteria enter the landfill primarily in the refuse and in the soil used to cover the refuse. Diversity of the populations is, therefore, to be expected. The goal of the study was to determine which of these organisms survive, which flourish and which contribute to the degradation of the waste. Due to the multipurpose nature of the study, the ecological approach has been selected. Two major computations of the bacterial database have been included, numerical taxonomy and principal components analysis. In addition, the inorganic chemical load has been analysed by factor analysis. Each of these multivariate statistical analyses extracts the essential variance in large data bases making it possible to profile the enviromental influences unencumbered by the minor variables.

Possible movement of the predominant population of bacteria through leachate and the ground water was determined by a cluster analysis of the matrix of similarity coefficients of each strain compared to every other strain which was generated from their responses to sixty-three tests. The responses reflected the physiological profile of the organisms and provided, in part, the information needed to identify the bacterial isolates. This same database was also analysed for the principal components of the variance which were then interpreted ecologically.

In essence, the questions being asked in this study are, which species survive in a municipal waste disposal facility and what is the potential for degradation of waste materials by these species? The facility being studied is commonly known as a sanitary landfill and is presently 100 hectares. The original disposal site was about 0.5 hectares and was opened approximately 50 years ago. The present site was cleared in 1972 and was excavated to $12-15 \mathrm{~m}$. The fill is a mixture of municipal and industrial materials. The areas are in varying stages of degradation - 


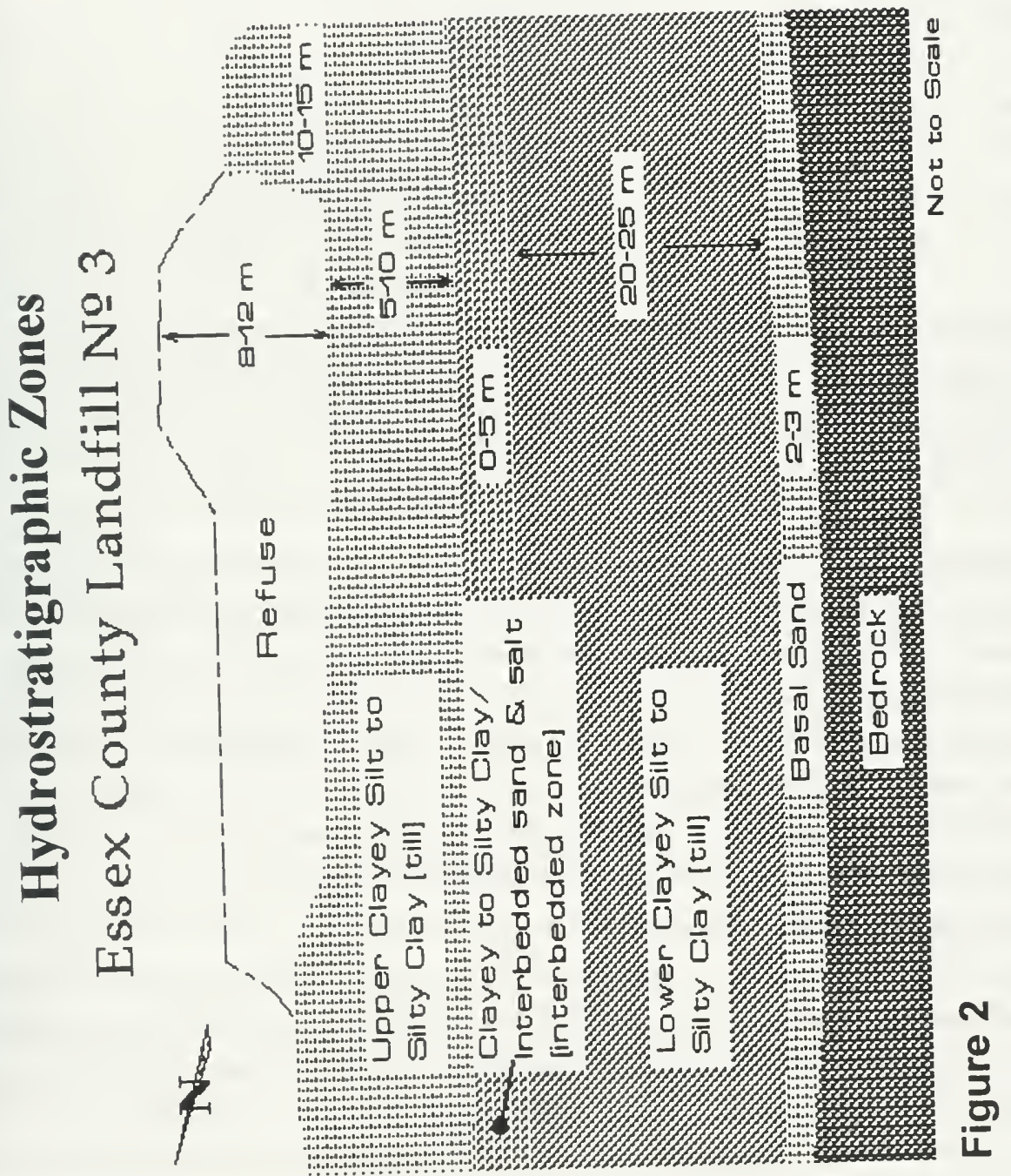


some having been capped for several years [Figure 1]. The landfill [\#3] is situated in Essex County, Ontario. The county is bordered by Lake St. Clair on the north, the Detroit River on the west, and Lake Erie to the south.

The microbiological study of landfill \#3 also included hydrogeological, geochemical and physical analysis. This report introduces an extensive study of the heterotrophic bacteria of this sanitary landfill. Although there are many organisms that assist in the degradation of landfill waste, the most important biodegraders are bacteria [Barlaz et al. 1989,1992]. Much is known of the activities of methanogens, the anaerobic bacteria that generate methane, but the initiation of degradation by the heterotrophic aerobes and facultative anaerobes is not as well described [Colby et al.1979, Hoeks, 1983]. The microbial components in a sanitary landfill include the organisms on and in the refuse itself and the microorganisms in the soil cover. There is a mixing of these organisms as the packing continues. Rain water will also contribute organisms and airborne spores due to wind movement. The water percolating through the various levels of refuse will add to the mixing process. The water within the landfill known as leachate is drained constantly from the mound and eventually is collected in a pond which is pumped and the leachate transported by tanker truck to a sewage treatment plant using secondary processing.

Geologically, the area is part of an extensive clay plain. The surficial deposits are mostly clayey silt to silty clay that ranges in thickness from $25-40 \mathrm{~m}$ which form an aquitard over the bedrock aquifer. [Desaulniers et al. 1981]. It has been suggested by Sklash and Ibrahim [1991], and Desaulniers that the aquitard is of sufficiently low permeability and thickness to be suitable for waste disposal. The hydrogeological and geochemical study reported here was part of an ongoing monitoring of the landfill by Jagger Hims Consulting Engineers (1992, 1994 ). The temperature, $\mathrm{pH}$ and specific conductivity of the leachate from each monitor was recorded. The ground water levels were measured to determine the direction of flow.

\subsubsection{Landfill Description (Figure 1)}

Area A1 was filled from the northeast comer moving west and south with the active face on Concession Road \#4 from 1972 to 1977. Area A2 was filled from 1928 - 1982. Areas A4 and C first received refuse in 1982. Areas C, B1 and 2 were filled in 1991. Table 1 shows the area and age of the refuse which was sampled for bacteria. The average monitor depth was $12 \mathrm{~m}$. The hydrostratigraphic zones are shown in Figure 2. The figure is a modification of the diagram in the Jagger Hims report. 
Table 1. Refuse monitors, age of refuse in years and numbers of bacteria isolated in colony forming units $\mathrm{mL}^{-1}$ [CFU $\mathrm{mL}^{-1}$ ].

\begin{tabular}{llcl} 
Monitor & Area & Age in Years & Bacteria \\
\cline { 3 - 3 } L32 & B1 & 5 & $1 \times 10^{6}$ \\
L36 & B2 & 5 & $1 \times 10^{5}$ \\
L6 & C & 10 & 2 \\
L10 & A4 & 10 & 2 \\
L28 & A1 & 14 & $4 \times 10^{1}$
\end{tabular}

2.1.2. Microbiological studies: Several aspects of the landfill microbial populations have been studied including the viable counts and more detailed studies of the populations at selected monitors in the refuse, brown till, interbedded zone and gray till as well as the leachate collecting manholes - one in the northwest corner (MH4) and one in the northeast comer of the landfill trench monitor.

Microbiological studies included the isolation and characterization of viable heterotrophic bacteria at certain monitors. Viable colony counts of ground water leachate bacteria were obtained. Plates with separated colonies provided the isolates for further analysis. The methods have been well described in our publications. [Holder-Franklin 1981]. A cluster analysis of the strains using the responses to a selected test base was performed to detect similarities in populations at the various monitors with the object of following the movement of predominant strains through the leachate into the ground water and eventually into the surrounding subsurface environment. Comparisons of populations using the predominant viable isolates has been successfully used by us in companing river water populations diumally and seasonally [Cormier and Holder-Franklin, 1981].

A specific search for $E$. coli and Salmonella within the leachate and ground water required special culturing techniques as these organisms are not usually part of the predominant population. Using the dilution/ isolation technique as was done for the colony counts restricts the isolates to those which are present in the greatest numbers. If present, E.coli would have to be in the predominant population to be detected by the plate count dilution method. The importance of the predominant viable, culturable population has been clearly demonstrated by the mathematically based model of population changes which we developed in previous studies on aquatic bacteria. 
The path analysis indicated that the predominant population was controlled by environmental influences. [Holder- Franklin 1992].

\subsubsection{Materials and Methods:}

2.2.1 Sampling Procedures: Samples were obtained in July, August, September and October, from the sub-soil refuse, the down gradient flow line, and the leachate collection wells which are designated manhole (MH4) and trench monitor ( TM), in addition, the leachate pond, the immediate periphery of the site at various depths, the interbedded zone and two sites $1,000 \mathrm{~m}$ and $1800 \mathrm{~m}$ from the site (Figure 1). Tubes of polyvinyl chloride of the appropriate length were thoroughly rinsed with dilute nitric acid followed by distilled water and fitted with a foot valve. Each monitor pipe was purged and the purged leachate in the standing pipe as well as the recharged leachate sampled for bacteria. The leachate samples were analyzed for temperature, specific conductivity, $\mathrm{pH}$, ground water levels and bacterial viable counts. Certain monitors were analysed for the total viable heterotrophic bacterial population. The standing pipe water was sampled to determine if the bacterial numbers would increase or decrease when kept away from the refuse or soil. The recharge of the pipe occurred within minutes but could require 24 hours during the dry weeks of that summer.

2.2.2. Colony Counts: The leachate or ground water samples were diluted from $10^{-1}$ to $10^{-5}$ and $0.1 \mathrm{ml}$ of the dilution series from undiluted to $10^{-5}$ was plated on nutrient (Difco) yeast agar (with added vitamins and minerals) (NYE) in duplicate, giving a dilution range of $10^{-1}-10^{-6}$. An additional duplicate set was incubated anaerobically. Plates were incubated at room temperature for 2 weeks. Colonies were examined after 48 hours and repeatedly throughout the incubation time.

2.2.3. E. coli and Salmonella Screening: Dilutions of leachate or ground water from all monitors sampled in this study were grown on MacConkey agar (Difco). Representatives of all colony types were subcultured in triple sugar iron (TSI) agar (DifCo) and the isolates tested to determine if $E$. coli and Salmonella species were present. Bacteria were identified using Bergey's Manual of Systematic Bacteriology [Krieg and Holt, 1984] and confirmed by serotyping. The tests used in identification are listed in Table 6 . Samples were also filtered and the filters placed on $M$-endo medium. Strains suspected of being $E$. coli or Salmonella were identified by Micro ID (Organon Tecnicon) in this part of the study.

2.2.4. Anaerobic Cultures: Dilutions of each sample were placed on NYE and incubated in sealed anaerobic jars with gas packs[BBL] for one week. The release of gas from the rehydrated 
pack creates anaerobic conditions. The growth on the anaerobic plates was subcultured to NYE agar plates in duplicate. All of the isolates were able to grow aerobically. The predominant population of organisms in leachate were facultative anaerobes.

2.2.5 Numerical Taxonomy: The isolates selected from the plates were transferred three times to ensure purity and kept on NYE slants. The numerical taxonomy program is based on UPGMA [unweighted pair group with arithmetic averaging] clustering of strains using the $S_{J}$ coefficient [Sneath, 1957]. The NTZ500 program of Wuest computed the clusters [Wuest 1981]. Colony and microscopic morphology were used for identification The tests selection was partly based on the previous numerical analysis of aquatic bacteria where the cluster formation index program DINDEX was linked to the numerical taxonomy program. In this way, tests that are useful for heterotrophic bacteria can be analysed. The pilot study for this project on the site $.5 \mathrm{Km}$ from the land fill at the Maidstone Township office indicated that soil and ground water bacteria responded to a modification of the aquatic data base.[Holder-Franklin et al. 1991]. As soil and waste bacteria were a major consideration in this study, the test base was further modified.

2.2.6 Biodegradative Capacity: The test responses were analysed according to the following categories using the feature frequency results as computed in the numerical program. Utilization of substrates, oxidation and fermentation of sugars, participation in nitrogen cycling, enzyme activity, ability to tolerate changes in $\mathrm{pH}$, temperature, oxygen levels, and specific conductivity (ion concentration). The test response groups are shown in Table 6. 
Table 2: Monitor Locations and Bacterial Viable Counts

\begin{tabular}{|c|c|c|c|}
\hline Monitor & Location & $\begin{array}{l}\text { Total Viable Count } \\
\text { CFU mL - }\end{array}$ & $\begin{array}{l}\text { MacConkey Plate Count } \\
\text { CFU mL - }\end{array}$ \\
\hline MH-4 \# surface & MH Surface & $4.30 E+04$ & $4.00 E+01$ \\
\hline TM \# surface & TM Surface & $1.25 \mathrm{E}+07$ & $6.50 \mathrm{E}+02$ \\
\hline $\mathrm{MH}-4$ & MH Surface & & $2.00 \mathrm{E}+04$ \\
\hline $11-111$ & Brown till pipe & $4.50 E+05$ & $2.10 \mathrm{E}+02$ \\
\hline $11-111 \#$ & Brown till & $4.50 E+04$ & $3.10 E+04$ \\
\hline 17.1 & Gray till pipe & $4.50 \mathrm{E}+04$ & $1.10 \mathrm{E}+03$ \\
\hline $17.1 \#$ & Gray till & $6.80 E+04$ & $1.80 E+03$ \\
\hline $21-2$ & Gray till & $7.00 \mathrm{E}+05$ & $7.90 E+03$ \\
\hline $16-1$ & Interbedded 1 & $5.00 E+05$ & $3.80 E+04$ \\
\hline $1-1$ & Interbedded 2 & $3.00 \mathrm{E}+01$ & $2.00 E+00$ \\
\hline $2-1$ & Interbedded 3 & $3.00 E+05$ & $2.60 E+04$ \\
\hline $41-1$ & Interbedded 4 & $2.00 E+03$ & $4.00 \mathrm{E}+02$ \\
\hline 26 & Interbedded 5 & $6.00 \mathrm{E}+05$ & $6.00 \mathrm{E}+03$ \\
\hline $11-1$ & Interbedded 6 & $7.00 \mathrm{E}+05$ & $8.70 E+04$ \\
\hline $39-1$ & Interbedded 7 & $8.40 E+06$ & $8.20 E+04$ \\
\hline 39.1 & Interbedded 8 & $3.00 E+03$ & $2.70 E+02$ \\
\hline 29 & Interbedded 9 & $9.50 E+04$ & $9.00 E+03$ \\
\hline 24 & Interbedded 10 & $4.00 \mathrm{E}+05$ & $2.50 \mathrm{E}+04$ \\
\hline $39-11$ & Intertedded 11 & $2.00 E+04$ & $1.00 E+03$ \\
\hline $39-11$ \# & Interbedded 12 & $3.40 E+04$ & $1.00 E+06$ \\
\hline $43-1$ & Interbedded 13 & $5.50 \mathrm{E}+05$ & $7.50 E+03$ \\
\hline 37 & Interbedded 14 & $3.80 E+04$ & $3.30 \mathrm{E}+03$ \\
\hline $46-1$ & Interbedded 15 & $8.40 E+04$ & $2.10 E+03$ \\
\hline L36 - - & Pipe refuse $L 36$ & $1.00 \mathrm{E}+05$ & $1.60 \mathrm{E}+04$ \\
\hline L36 - 2 & Refuse L36 & $1.00 \mathrm{E}+06$ & $1.50 E+05$ \\
\hline$-28-\mathrm{VI}-1$ & Pipe refuse L28 & & $4.00 \mathrm{E}+01$ \\
\hline L28-VI -2 & Refuse L28 & $4.00 \mathrm{E}+01$ & $4.00 \mathrm{E}+01$ \\
\hline L6 -1\# & Pipe refuse L6 & $1.10 \mathrm{E}+04$ & $1.00 \mathrm{E}+06$ \\
\hline L6 -2\# & Refuse L6 & $2.00 E+00$ & $1.00 \mathrm{E}+00$ \\
\hline L10 - 1 & Pipe refuse L10 & $3.00 E+04$ & $5.50 E+03$ \\
\hline L10 -2 & Refuse L10 & $2.00 E+00$ & \\
\hline L32 \# & Refuse L32 & $2.50 E+07$ & $1.00 E+06$ \\
\hline
\end{tabular}

CFU - Colony Forming Units $\mathrm{mL}^{-1}$

Low counts: Interbedded 1-I

$\begin{array}{ll}\text { Refuse } & \mathrm{L}-28 \\ \text { Refuse } & \mathrm{L}-6\end{array}$

High counts Trench monitor Interbedded 39-1 Refuse
L-32

Low counts more frequently seen in refuse monitors [Table 1]. High counts were related to newer refuse and leachate. Some impact from the land fill may be seen in monitor 39-I. Nineteen monitors were in the $10^{4}-10^{5} \mathrm{CFU} \mathrm{mL}^{-1}$ range and four in the $10^{6}-10^{7}$ range. 


\subsubsection{Results:}

\subsubsection{Groundwater Chemistry :}

Specific conductivity: as can be observed in figure 3 , the specific conductivity for all monitors is high. In the leachate from refuse it is extremely high, reaching $>50,000 \mathrm{~m}$ Siemens $\mathrm{mL}^{-1}$ in monitor L6. All samples were tested for an array of ions and organic compounds. The L6 monitor sample contained $23,500 \mathrm{mgL}^{-1} \mathrm{Cl}^{-}$and $13,700 \mathrm{mgL}^{-1} \mathrm{Na}^{+}$. The low number of viable bacteria could be explained by the concentration of $\mathrm{NaCl}$ alone. The isolates from the L6 sample had to be cultivated by enrichment. The concentration of $\mathrm{SO}_{4}{ }^{2-}$ is generally low in these samples but is somewhat higher in $\mathrm{L} 6$ apparently due to the suppression of $\mathrm{SO}_{4}{ }^{2-}$ reducing bacteria by the high salt concentration. On the other hand, the low nitrates and nitrites in the samples could be attributed to the action of nitrate and nitrite reducing bacteria which may be more salt tolerant. At the time of sampling, the $\mathrm{NaCl}$ concentration had not been determined or a high salt medium would have been used for the isolation.

$\mathrm{pH}$ - the $\mathrm{pH}$ range of leachate and ground water was 6.2 to 8.5 which will support most heterotrophic bacteria [figure 4].

Temperature - the temperature range in the brown and gray till as well as the interbedded zone and at the manhole collection point varied from $9^{\circ}-16.5^{\circ} \mathrm{C}$. Refuse temperatures were higher reaching $31.5^{\circ}$ in L6.[figure 5]. Certain bacteria will not be encouraged to grow at these temperatures but there was a healthy population of organisms at most non-refuse monitors. The higher temperatures in L6 gave an indication of microbial activity. It was assumed that methanogens and other anaerobes would not be isolated using the methods employed here. Temperatures in the leachate from the refuse monitors varied from $20^{\circ} \mathrm{C}$ to $33^{\circ} \mathrm{C}$ which would support the growth of most heterotrophic bacteria. The younger refuse yielded higher numbers of heterotrophic aerobic bacteria [Table 1].

\subsubsection{Bacterial Colony Counts:}

Table 2 shows the colony counts of the leachate from 32 monitors. The location is noted and groundwater levels have been included. Counts of monitors from several areas and at varying depths are shown in Figure 6. The MacConkey agar plates yielded lower counts with two exceptions and no rationale was apparent. Colonies isolated from MacConkey agar were tested for $E$. coli and Salmonella from leachate and ground water and not detected. 
Legend figures $3,4,5$

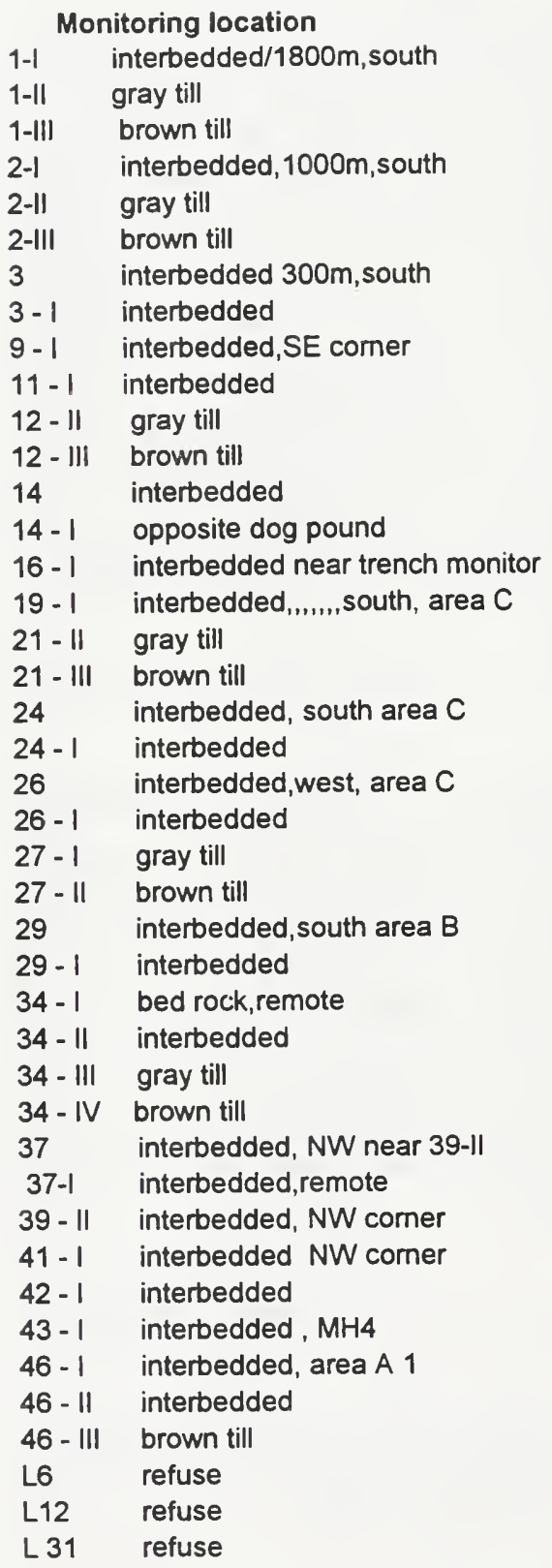



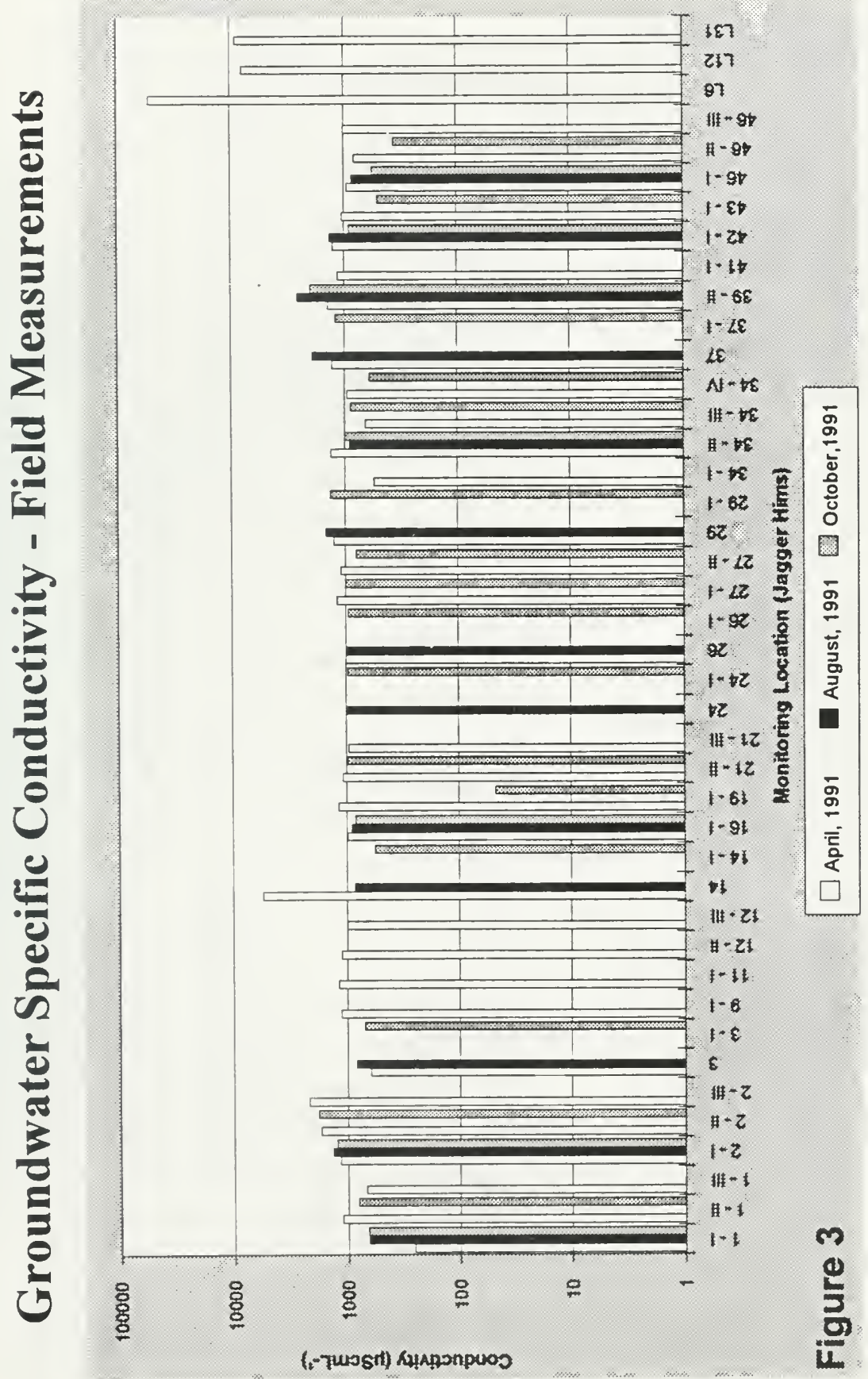
ט.

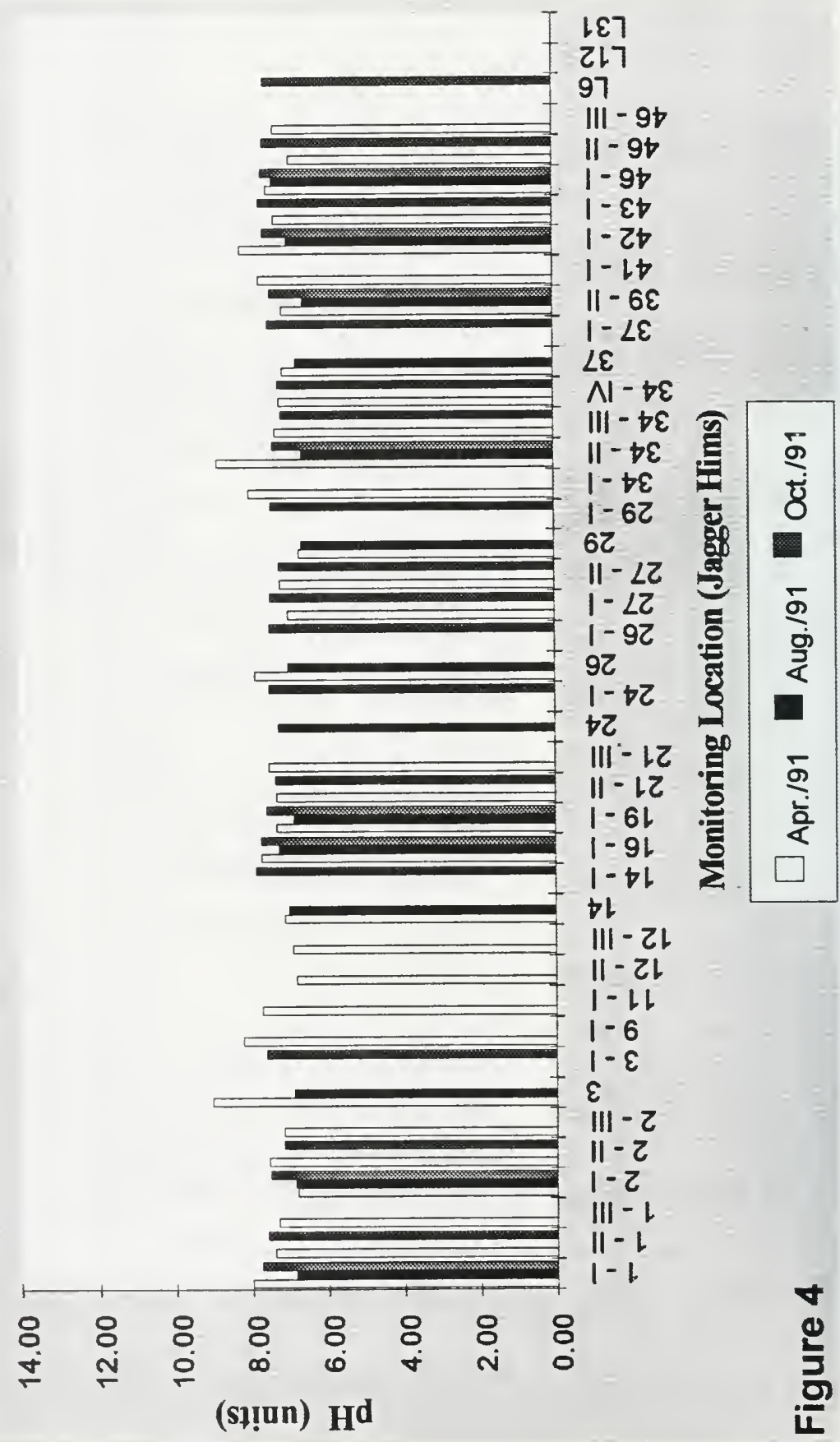



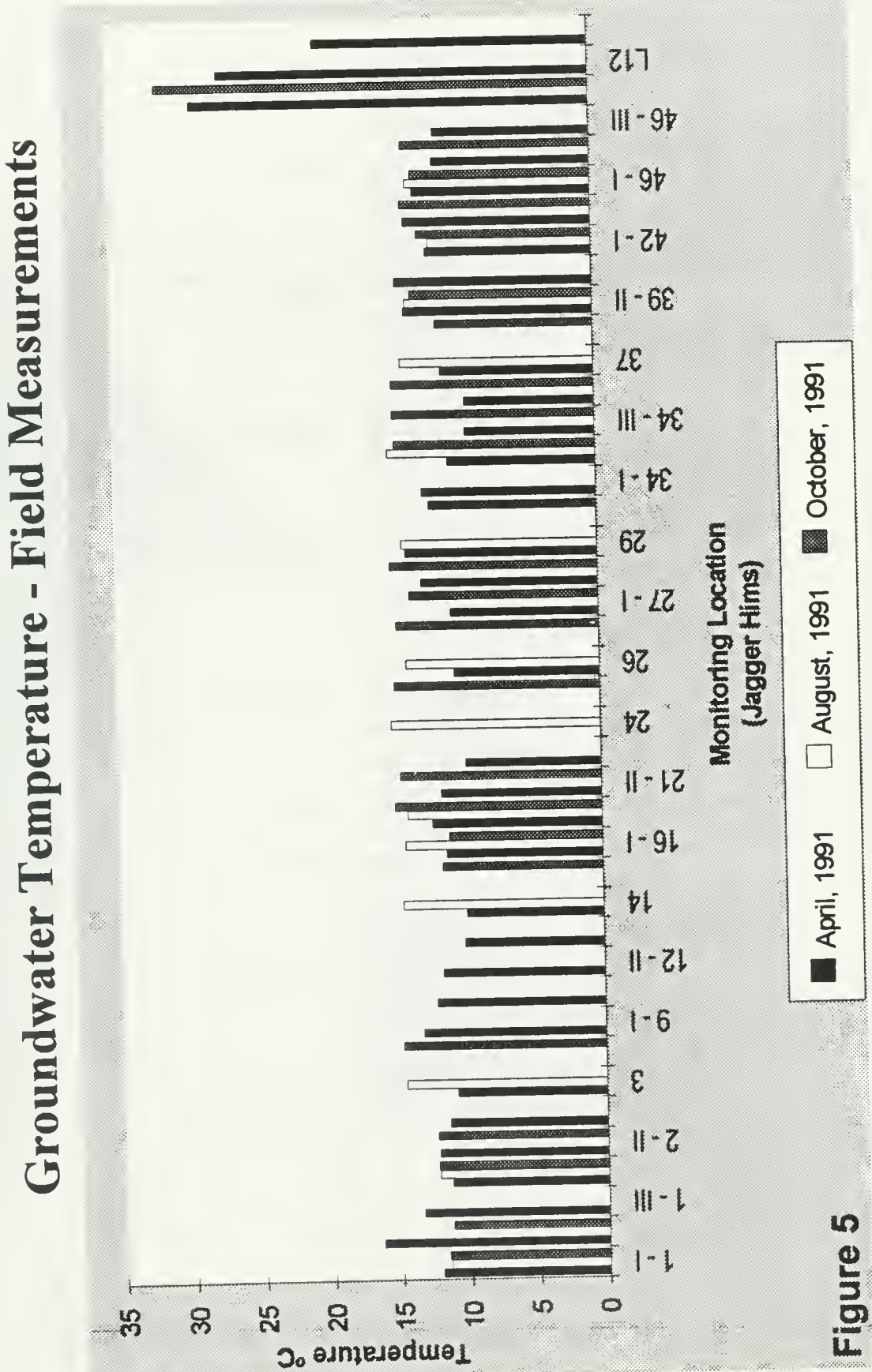
年
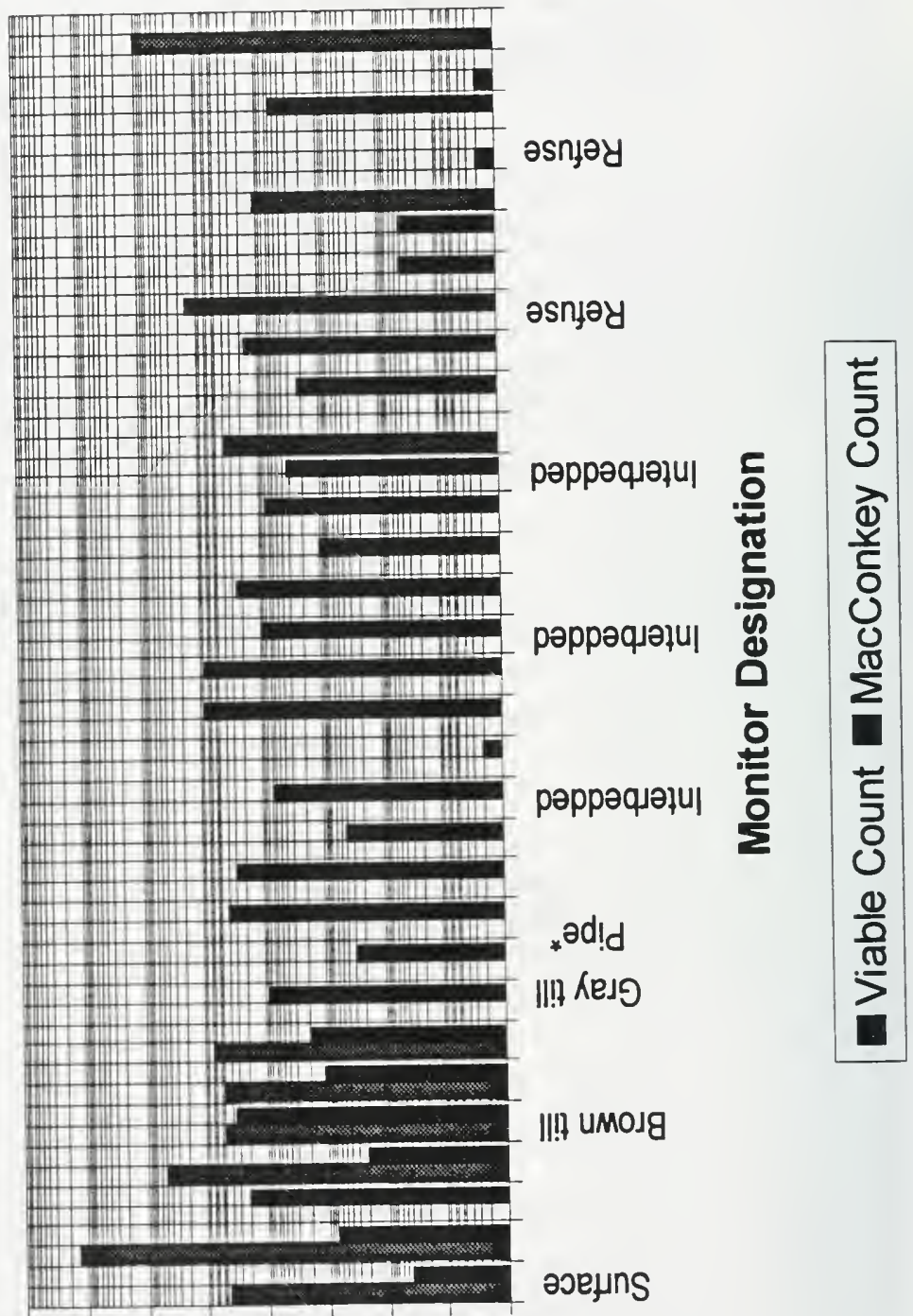

II! UMOJg

әวенn'

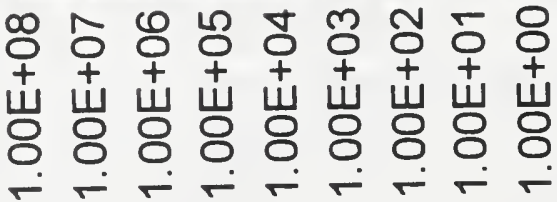

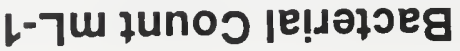


Figure 7

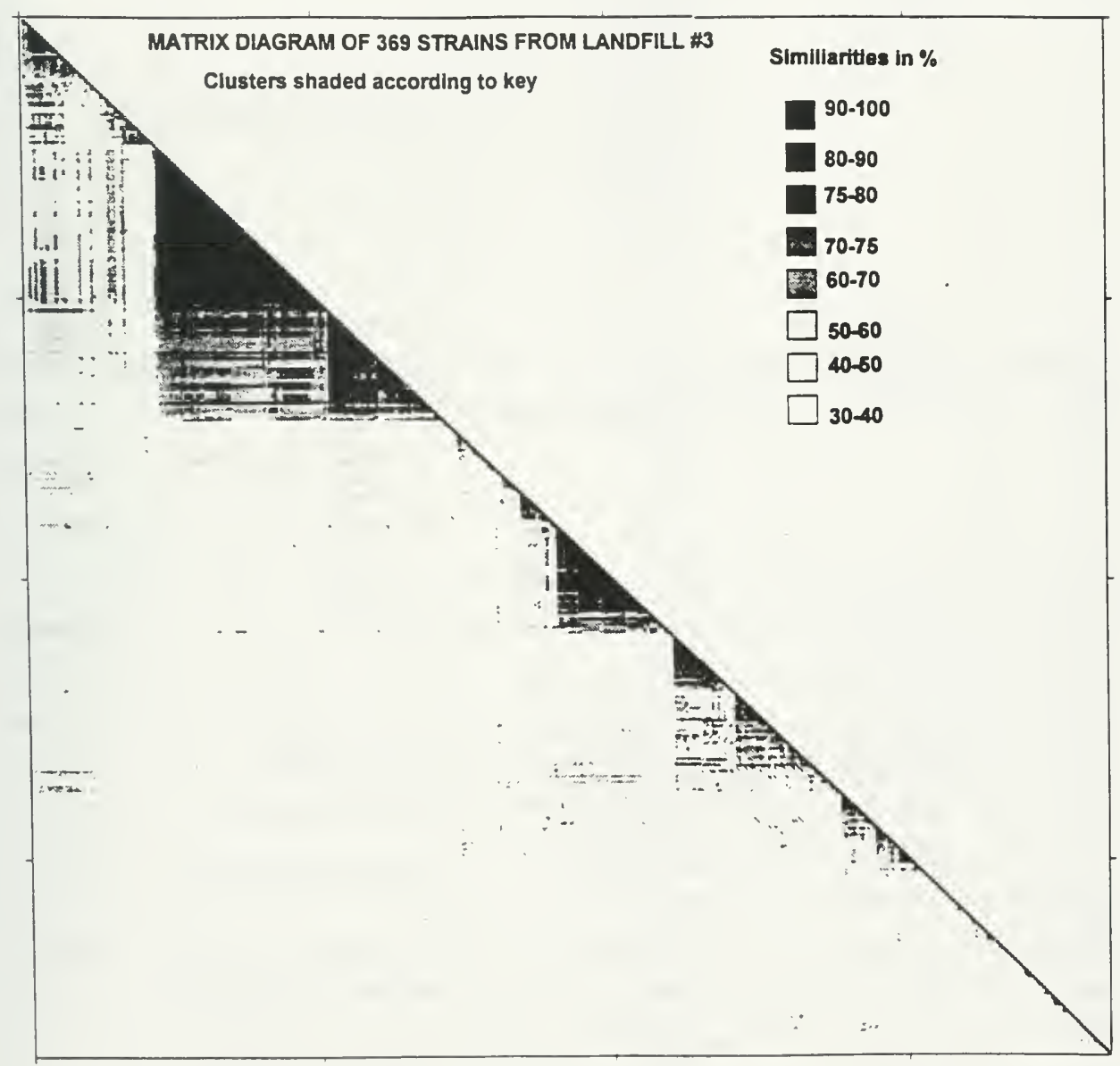


Table 3: Tree Matrix of July Sampling:

Cluster \# Location Coefficients Identification

\begin{tabular}{|c|c|c|c|c|}
\hline 1 & Gray till & 0.714 & & \\
\hline 2 & Trench & 0.659 & & \\
\hline 3 & Brown till & & & \\
\hline 4 & Brown till & 0.793 & & \\
\hline 5 & & 0.903 & & \\
\hline 6 & & 0.938 & & Pseudomonas aurantiaca \\
\hline 7 & & 0.855 & & \\
\hline 8 & & 0.821 & $\# 1$ & \\
\hline 9 & & 0.905 & & \\
\hline 10 & & 0.761 & & \\
\hline 11 & & 0.783 & & \\
\hline 12 & & لـ & & \\
\hline 13 & Leachate & 0.8377 & & Azomonas insignis \\
\hline 14 & Trench & 0.714 & \#2 & \\
\hline 15 & Gray till & 0.8007 & & Azomonas macrocytogenes \\
\hline 16 & & ] & $\# 3$ & \\
\hline 17 & & 0.658 & & \\
\hline 18 & & 0.589 & & \\
\hline 19 & & 0.744 & & \\
\hline 20 & & 0.575 & & \\
\hline 21 & & 0.617 & & \\
\hline 22 & & 0.654 & & \\
\hline 23 & & 0.727 & & \\
\hline 24 & & 0.583 & & \\
\hline 25 & & 0.544 & & \\
\hline 26 & & 0.725 & & \\
\hline 27 & Leachate & 0.8007 & & Vibrio nereis \\
\hline 28 & Leachate & 0.644 & $\# 4$ & \\
\hline 29 & Gray till & 0.8247 & \#5 & Citrobacter freundii \\
\hline 30 & Gray till & 0.703 & & \\
\hline 31 & Gray till & 0.7757 & & Enterobacter cloacae \\
\hline 32 & Gray till & لـ & $\# 6$ & \\
\hline 33 & & 0.739 & & \\
\hline 34 & Leachate & 0.9237 & & Aeromonas salmonicida \\
\hline 35 & & 0.891 & $\# 7$ & Aeromonas hydrophila \\
\hline 36 & & ] & & \\
\hline 37 & Gray till & 1.0007 & & Kingella indologenes \\
\hline 38 & & 0.971 & & Kingella indologenes \\
\hline 39 & & 0.941 & \#8 & Kingella indologenes \\
\hline 40 & & 0.905 & & Kingella denitrificans \\
\hline 41 & & 0.435 & & Kingella denitrificans \\
\hline
\end{tabular}


Table 4. Mean intergroup coefficients of July isolates.

Cluster \#1Compared with Cluster

\#

2

3

4

5

6

7

8
Mean

$72.7 \pm 5.88$

$71.8+6.17$

$66.4 \pm 4.16$

$50.1 \pm 4.10$

$61.2 \pm 5.15$

$64.6 \pm 5.15$

$58.1 \pm 5.15$

Table 4 contains the mean intergroup coefficients which demonstrates there is a strong similarity between the first three clusters indeed the mean intergroup coefficient between clusters 2 and 3 is $69.4 \pm 4.11$. [not shown in table]

\subsubsection{Numerical Taxonomy: July}

The tree matrix (Table 3) which shows the order of the strains also shows the similarity coefficients of the strains. Beginning at the top, the first coefficient is the similarity of strain 1 to strain 2, the second strain 2 to strain 3. These coefficients are clustered at 0.75 . Clustering commenced at strain 3 with cluster \#1 and continued to strain 12 . The identifications are placed opposite the strain identified. The clusters were homogeneous with the exceptions of those designated in clusters 7 and 8 as different species but the same genus. The clusters were composed of strains from a single site i.e. each cluster represented a distinctive site with the exception of cluster 2, Azomonas insignis. The second strain in that cluster may be a variant of the insignis species as it does not have a fluorescent pigment and the diffusible pigment is orange/brown. With the exception of cyst formation - the strain resembles Azotobacter. It does fix $\mathrm{N}_{2}$ and does not denitrify or use glutamate as a sole carbon source. Cluster \#1 of 10 strains was a mixture of 2 gray till and 8 brown till isolates. These samples were obtained from the periphery on the east side of the landfill several hundred yards apart but connected by the drainage pipe. Cluster \#2 is composed of two strains, one from the leachate and one from the trench, indicating some common source. Because numerical taxonomy of isolates obtained by the dilution technique pin points only the predominant strains within the clusters, populations can be compared with each other at the most numerous level, thus allowing a clearer interpretation of 
the ecological significance. Strains isolated from distinctly different econiches have a unique set of physiological characteristics due to the pressures of the environment.

2.3.4 September and October sampling of the refuse yielded 316 strains which formed 32 clusters. These are shown in figures 7 and Table 5. Identifications followed Bergey's Manual [Kreig and Holt, 1984] and tests such as those for oxidase, fermentation of sugars and nitrate reductase and nitrogen fixation were important guides to the genera. Very distinctive characteristics such as colonial morphology and pigment production as well as poly- $\beta$-hydroxybutyrate accumulation were aids in the speciation. The motility or flagella position was rarely noted as these are not as reliable as the enzyme reactions. The organisms found in the interbedded zone, monitor 39 II, are found in soil, and water and little impact of the landfill is seen with the exception of Alkaligenes denitrificans subspecies xylosoxydans which belongs to the knall gas group of bacteria, common to leachate. In the landfill report of 1991, Jagger Hims identified this monitor as having fluctuating hydrological characteristics and some possible effects from the leachate. The same sample yielded Pseudomonas marina, now moved to an entirely new group the Halomonadaceae and a new genus Deleya marina which has been described as a marine form which is not an obligate halophile [Balows et al. 1992]. This is not surprising due to the high salt content of the ground water in Essex County and the geological history. There were several manine forms isolated from ground water in our studies. The medium used for isolation contained mineral salts and $\mathrm{NaCl}$ as these are often required by bacteria isolated from the soil and water environment. The presence of marine forms in fresh water has also been reported in our previous studies on the St. John River in New Brunswick [Holder-Franklin, 1981].

\subsubsection{Numerical analysis of combined test results ; July, September and October:Figure 7.}

The matrix diagram of 369 strains shows the similarity coefficient relationships of all isolates based on the test responses. The compression of the data base demonstrates the overall profile of the population clusters. Essentially, there was little mixing of the clusters by date or location. The July strains yielded more positive test results. The mean feature frequency of tests for July was $54.8-69 \%$, for September $15.7-40.5 \%$. The strains isolated from all sources clustered according to the sample. When the three sets of data were combined some rearrangement of the order did appear. The 54 July strains occupy the top of the matrix with the exception of a cluster of October strains which appear in this analysis as cluster \#4. All of the clusters remained intact but the ordering changed outside of the clusters. The July clusters 2 and 3 as shown on Table 3 are reversed and this is due to the insertion of the October cluster \#24 [Table 5] into the combined analysis as cluster \#4. Following that insert, the remainder of the July clusters were in 
the same order. This can be seen in figure 10. The non-clustered strains moved to positions further down in the ordering after the large September clusters. The numerical analysis includes an extensive internal analysis which validates the statisical computations. One of these compares each cluster to every other cluster indicating the mean of the coefficients within the clusters. The first four clusters from the combined analysis of 369 strains isolated in July, September and October are compared in Table 7.

\section{Table 7: Mean Intergroup Coefficients of 4 Clusters from Combined Analysis}

Clusters compared Mean

$\begin{array}{ll}\text { Cluster } 1 \text { - cluster } 2 & 71.8 \pm 6.17 \\ \text { Cluster } 1 \text { - cluster } 3 & 72.7 \pm 5.90 \\ \text { Cluster } 2 \text { - cluster } 3 & 69.4 \pm 4.10 \\ \text { Cluster } 2 \text { - cluster } 4 & 70.5 \pm 4.90 \\ \text { Cluster } 3 \text { - cluster } 4 & 73.8 \pm 5.99\end{array}$

Clusters 1,2 and 3 have high similarities. The ordering was very robust and remained intact. The strong similarity between cluster 3 and 4 explains the introduction of an October cluster into the July sequence. Cluster 3 is Azomonas macrocytogenes isolated from the gray till. Cluster 4 shown on Table 5 as \#24 and identified as Azotobacter vinelandii was isolated from the interbedded zone. Both of these classifications describe nitrogen fixing soil organisms.

\subsubsection{Biodegradative Capacity:}

Figures 8 and 9 illustrate the physiological activity of the predominant isolates. The October isolates were more active than the September isolates in all categories. The most notable difference was observed in the physiological activity which included oxidation and fermentation of a variety of sugars, all stages in the nitrogen cycle and the catabolism of two amino acids. The variety of other activities indicates a moderately versatile community. Refuse and leachate populations are not as active as the native populations in soil and water and where low numbers were also observed, it was clear that the process of biodegration has been impeded.

When assessing the metabolic interactions of the bacteria, three strains should be noted. First, the chemolithotroph, Alcaligenes denitrificans sub- species xylosoxydans, has a selective advantage due to the potential to utilize gaseous hydrogen as an electron donor with oxygen as an electron acceptor, and to fix $\mathrm{CO}_{2}$ and nitrogen. Although this strain was isolated from the 
interbedded zone, the flexibility to switch from chemolithotrophy to heterotrophy gives the species a special advantage in leachate where it is often observed. This same monitor 39 II produced a viable culture of Bacillus pumilus, a cellulolytic species. The majority of the species isolated from the interbedded zone were versatile soil bacteria indicating that the leachate impact was not the strongest influence.

\section{Table 5}

Clustered Strains in Groundwater in Hydrostratigraphic Zones of Landfill \#3 - September, October

Mean Intragroup Coefficients in Percent Similarity and Identification of Cluster Centroids

\begin{tabular}{|c|c|c|c|c|c|c|}
\hline \multirow[b]{2}{*}{ Cluster \# } & \multirow[b]{2}{*}{ Location } & \multicolumn{2}{|c|}{$\begin{array}{l}\text { \# of } \\
\text { Strains }\end{array}$} & \multirow[b]{2}{*}{ Mean } & \multirow[b]{2}{*}{$\begin{array}{l}\text { Stan. } \\
\text { Dev }\end{array}$} & \multirow[b]{2}{*}{ Identification } \\
\hline & & Sept & Oct. & & & \\
\hline 1 & L32 & 9 & & 82.1 & 4.6 & Azomonas \\
\hline 2 & L32 & 7 & & 80.3 & 5.7 & Vibrio fluvialis \\
\hline 3 & L32 & 10 & & 77.2 & 5.7 & Eikenella corrodens \\
\hline 4 & L32 & 3 & & 78.7 & 5.7 & Aeromonas salmonicida subsp. salmonicida \\
\hline 5 & L32 & 3 & & 79.7 & 7.1 & Alcaligenes denitrificans \\
\hline 6 & L32 & 3 & & 80.6 & 6.0 & Alcaligenes denitrificans \\
\hline 7 & L32 & 2 & & 85.0 & 0.0 & Edwardsiella ictaluri \\
\hline 8 & L32 & 2 & & 80.0 & 0.0 & Alcaligenes denitrificans \\
\hline 9 & L32 & 2 & & 83.3 & 0.0 & Pseudomonas solanacearum \\
\hline 10 & L32 & 6 & & 82.3 & 6.5 & Alcaligenes denitrificans subsp. xylosoxydans \\
\hline 11 & L32 & 2 & & 100.0 & 0.0 & Alcaligenes denitrificans \\
\hline 12 & L6-1 & 2 & & 94.1 & 0.0 & Acetobacter hansenii \\
\hline 13 & L32 & 4 & & 79.1 & 6.1 & Kingella kingae \\
\hline 14 & L32 & 2 & & 80.0 & 0.0 & Pseudomonas cepacia \\
\hline 15 & L6-1 & 5 & & 89.8 & 5.0 & Corynebacterium pseudodiphtheriticum \\
\hline 16 & L6-1 & 2 & & 87.5 & 0.0 & Francisella novicida \\
\hline 17 & $39-11$ & & 6 & 80.0 & 8.2 & $\begin{array}{l}\text { Pseudomonas marina, Acinetobacter calcoaceticus, } \\
\text { Alcaligenes denitrificans subsp. xylosoxydans }\end{array}$ \\
\hline 18 & L6-1 & 2 & & 81.8 & 0.0 & $\begin{array}{l}\text { Pseudomonas avenae, Alcaligenes denitrificans subsp. } \\
\text { denitrificans }\end{array}$ \\
\hline 19 & $39-11$ & & 30 & 85.4 & 8.0 & Pseudomonas cepacia, Pseudomonas stutzeri \\
\hline 20 & $39-11$ & & 3 & 82.4 & 3.6 & Pseudomonas pseudoalcaligenes \\
\hline 21 & L6-2 & 59 & & 87.6 & 6.0 & Enterobacter aerogenes \\
\hline 22 & L6-2 & 36 & & 83.0 & 6.3 & Serratia liquefaciens \\
\hline 23 & L6-2 & 2 & & 84.4 & 0.0 & Aeromonas sobria \\
\hline 24 & $39-11$ & & 3 & 85.0 & 0.1 & Azotobacter vinelandii \\
\hline 25 & L6-1 & 2 & & 81.5 & 0.0 & Corynebacterium sp. \\
\hline 26 & L32 & 2 & & 83.3 & 0.0 & Zymomonas mobilis \\
\hline 27 & $39-11$ & & 2 & 84.6 & 0.0 & Bacillus pumilus \\
\hline 28 & L6-1 & 2 & & 80.0 & 0.0 & Bacillus brevis \\
\hline 29 & $39-11$ & & 2 & 75.0 & 0.0 & Xanthomonas ampelina \\
\hline 30 & L32 & 2 & & 80.0 & 0.0 & Pseudomonas diminuta \\
\hline 31 & L6-1 & 3 & & 81.5 & 8.6 & Alcaligenes sp. \\
\hline 32 & L6-1 & 2 & & 100.0 & 0.0 & Pseudomonas sp. \\
\hline
\end{tabular}


Table 6: Numerical Taxonomy Tests

\begin{tabular}{|c|c|c|}
\hline $\begin{array}{l}\text { Substrate } \\
\text { Utilization }\end{array}$ & Tolerance to Inhibitors & Other Physiological Activity \\
\hline DL-lactate & $0.1 \%$ basic fuchsin & $\mathrm{H}_{2} \mathrm{~S}$ Cysteine \\
\hline D-Glucose & $0.008 \% \mathrm{KCN}$ & B Hydroxybutyrate accumulation \\
\hline DL-Malate & $\mathrm{pH} 10.0$ & Acetoin Production \\
\hline L-Glutamate & $\mathrm{pH} 6.8$ & Glucose Fermentation to $\mathrm{pH} 5.0$ \\
\hline Laurate & $\mathrm{pH} 5.7$ & $\mathrm{~N}_{2}$ Fixation \\
\hline Pyruvate & $15 \% \mathrm{NaCl}$ & $\mathrm{NO}_{3}-\mathrm{NO}_{2}$ Reduction \\
\hline Fumarate & $10 \% \mathrm{NaCl}$ & $\mathrm{NO}_{2}-\mathrm{N}_{2}$ Reduction \\
\hline D-Fructose & $7 \% \mathrm{NaCl}$ & Denitrification \\
\hline Aconitate & $2 \% \mathrm{NaCl}$ & Indole Production \\
\hline DL-Arginine & & (Oxidation) Glucose \\
\hline Hydroxy-Proline & Enzyme & (Fermentation) Glucose \\
\hline Putrescine & Urea & (O) Lactose \\
\hline D-Trehalose & Arginine dihydrolase & (F) Lactose \\
\hline B Hydroxybutyrate & Omithine decarboxylase & (O) Fructose \\
\hline D-Betaine & Gelatin liquefaction & (F) Fructose \\
\hline D-Cellobiose & Starch hydrolysis & (O) Sucrose \\
\hline L-Alanine & Catalase & (F) Sucrose \\
\hline D-Xylose & Oxidase & (O) Mannitol \\
\hline D-Arabitol & Esculin hydrolysis & (F) Mannitol \\
\hline Ethanolamine & Lysine decarboxylase & \\
\hline D-Ribose & & Identification* \\
\hline L-Leucine & & Gram stain;Phenazine pigment \\
\hline Cysteine & & Fluorescent pigment \\
\hline
\end{tabular}




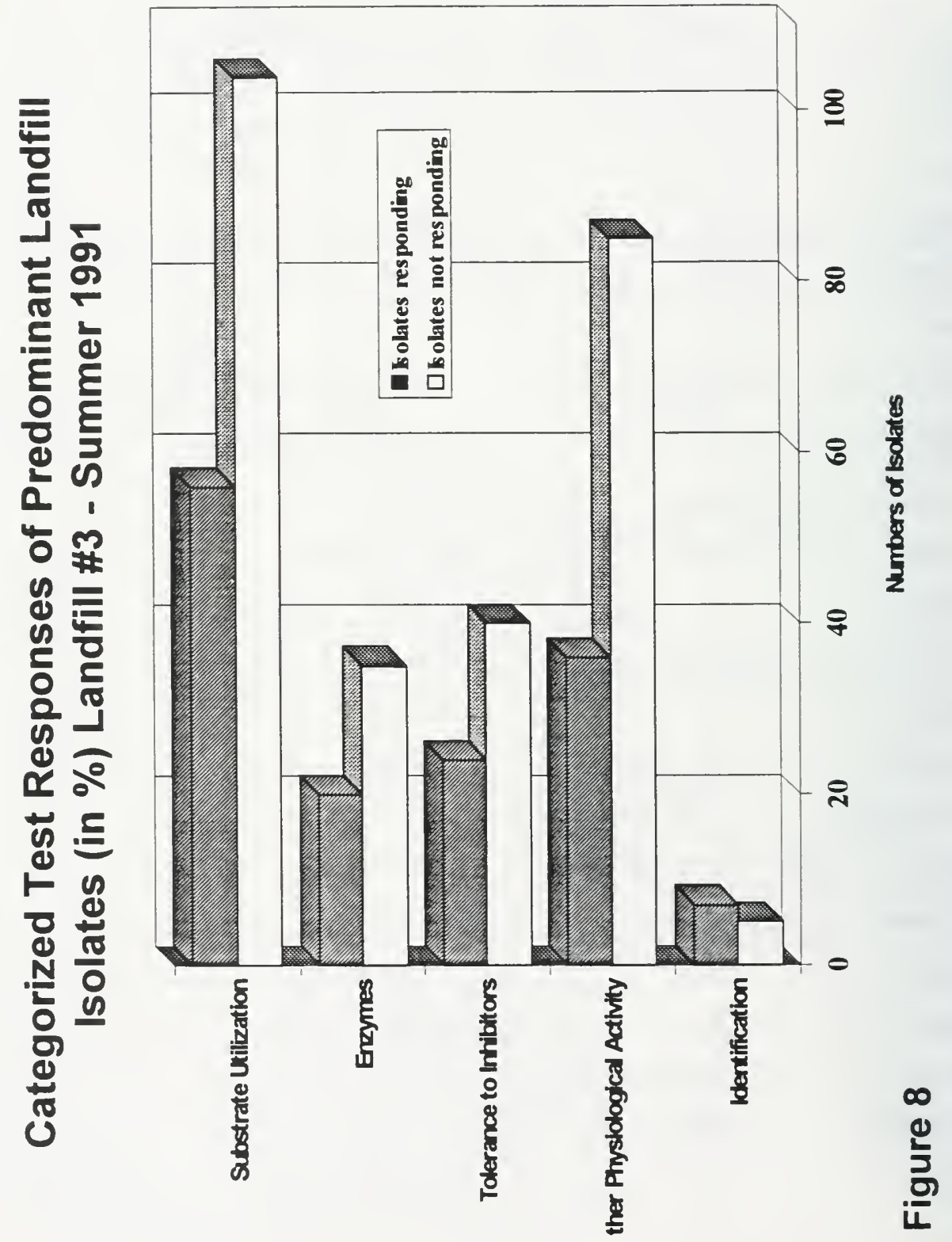




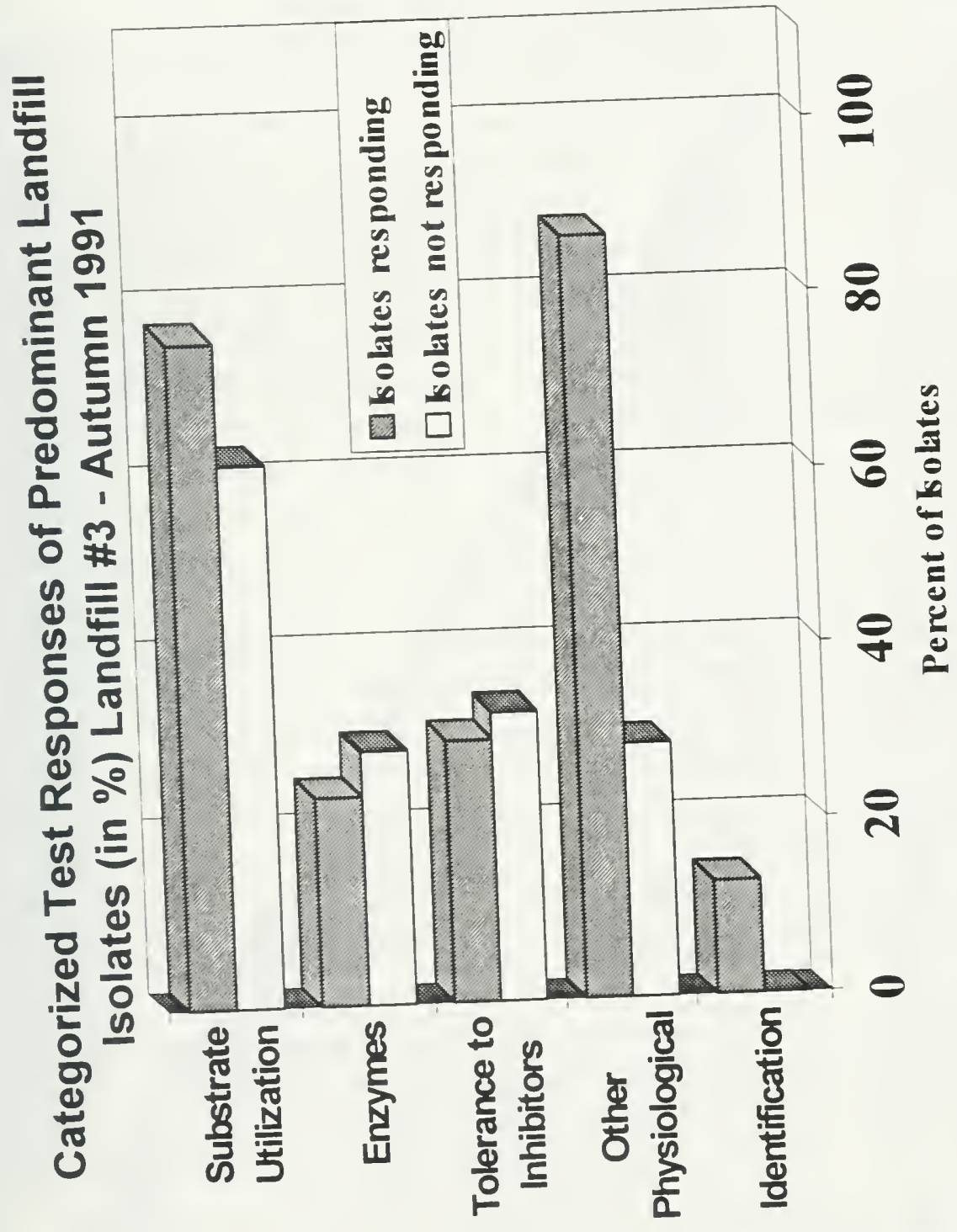

$\frac{1}{2}$ 


\section{FIGURE 10}

SERIES

STFIAIN

NUMBEF

\begin{tabular}{|c|c|c|}
\hline LEJ & 101 & 1 \\
\hline$L=J$ & $=15$ & $=$ \\
\hline LこJ & 305 & $=$ \\
\hline LتJ & $=11$ & 4 \\
\hline LذJ & $=17$ & 5 \\
\hline โ3J & 318 & 6 \\
\hline LこJ & 319 & 7 \\
\hline L3J & 321 & 8 \\
\hline L3J & 320 & 9 \\
\hline LJJ & 322 & 10 \\
\hline L3J & 124 & 11 \\
\hline L3J & 126 & 12 \\
\hline L3J & 127 & 13 \\
\hline LこJ & 128 & 14 \\
\hline LJJ & 432 & 15 \\
\hline Lこ̃J & 239 & 16 \\
\hline L30 & 122 & 17 \\
\hline L30 & 144 & 18 \\
\hline L3O & 169 & 19 \\
\hline LउJ & 430 & 20 \\
\hline L3J & 250 & 21 \\
\hline L3J & 306 & 22 \\
\hline L3J & 413 & 23 \\
\hline L3J & 414 & 24 \\
\hline LJJ & 216 & 25 \\
\hline L3J & 235 & 26 \\
\hline L3J & 407 & 27 \\
\hline L3J & 408 & 28 \\
\hline LउJ & 203 & 29 \\
\hline LJJ & 434 & 30 \\
\hline LこI & 454 & 31 \\
\hline LJJ & 123 & 32 \\
\hline L3J & 125 & 33 \\
\hline LJJ & 141 & 34 \\
\hline L3J & 146 & 35 \\
\hline LJJ & 433 & 36 \\
\hline LJJ & 451 & 37 \\
\hline L3J & 453 & 38 \\
\hline L3J & 452 & 39 \\
\hline LJJ & 140 & 40 \\
\hline LउJ & 143 & 41 \\
\hline L3J & 145 & 42 \\
\hline L3J & 142 & 43 \\
\hline LIJ & 144 & 44 \\
\hline L3S & $=65$ & 45 \\
\hline LJS & 192 & 46 \\
\hline L3S & 200 & 47 \\
\hline LJS & 204 & 48 \\
\hline L3S & 202 & 49 \\
\hline LisS & 210 & 50 \\
\hline LIS & $=01$ & 51 \\
\hline L3S & $=08$ & 52 \\
\hline L35 & $=12$ & 53 \\
\hline
\end{tabular}

COMBINED CLUSTER ANALYSIS MATRIX

July, September,October : first 53 strains of 369

$1=4 \quad$ = $4 \quad 5$ $1=3456789012=4567890127456789012=456789012=456789012=4567890$

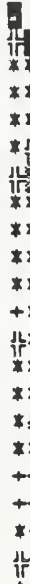

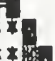

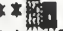

\& 3

fuil $\rightarrow$ :

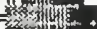

+2 tri

$*+5 ; x$

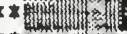

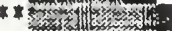

++41 .

12***********1

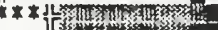

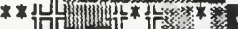

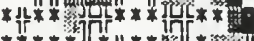

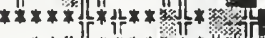

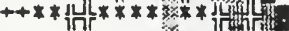

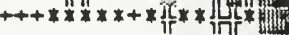

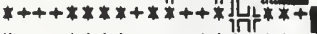

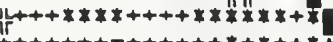

$+++++++=++++++*+*++*+$

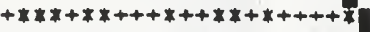

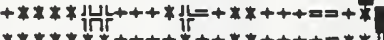

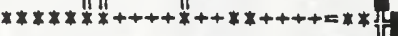

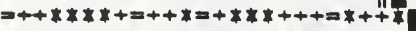

$+* * 11 * * * * * *++* * *+++=a+++x++=$

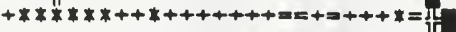

$+++*+* *++++++*+=++++=+*++=*+$

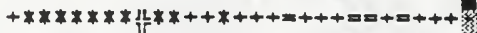

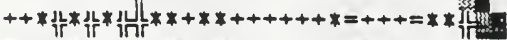

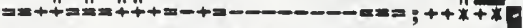

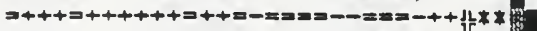

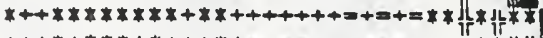

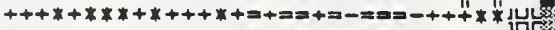

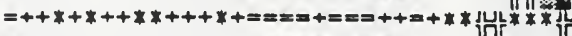

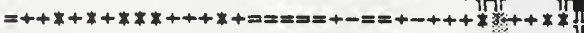

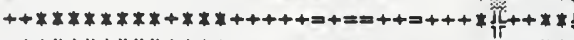

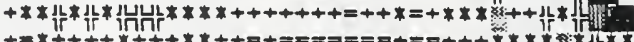

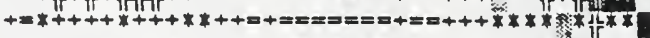

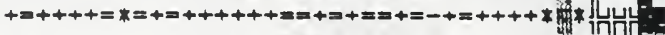

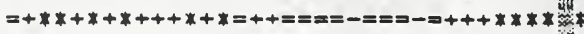

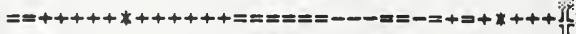

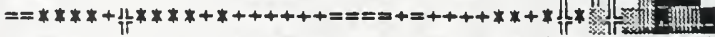

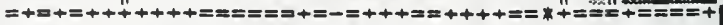

$=+=+=++++=++=+====+==0+++==++++++*++++++++=+X$

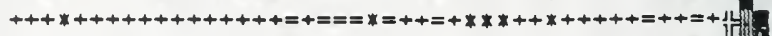

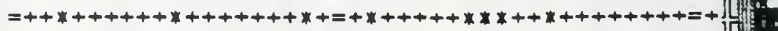

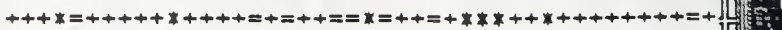

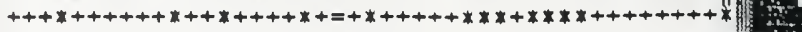

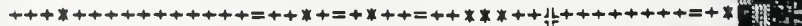

$+++++++++++=++=0+=++==+=+==+* * *++*+1)$

$+++x+x \times+++++++++++x+=+x+++++x \times x++x+++++====+x \mid x$ 


\subsubsection{Discussion:}

Microbial populations recovered from a sanitary landfill have been investigated for biodegradative capacity, human pathogens and impact on ground and surface water using cluster analysis of physiological responses, Biolog ${ }^{\mathrm{TM}}$ and GeneTrak ${ }^{\mathrm{TM}}$. Active bacteria capable of biodegradation were isolated from refuse leachate. High ion concentrations suppressed the bacteria from two sites. Ground water bacteria typical of uncontaminated sub-surface sites were unique to each site indicating no connection through the hydrostratigraphic zones. Surface water samples contained E. coli and Salmonella sp. from animal not landfill sources.

The study was designed to determine if bacteria which are introduced into the sanitary landfill remain within the site and contribute to the biodegradation of the refuse. The heterotrophic bacteria which enter the landfill from refuse, soil and water would not be inhibited by the $\mathrm{pH}$ and temperature of the leachate or groundwater. The ion concentration of certain refuse monitors would and did, suppress bacterial giowth. E.coli and Salmonella do not survive in the landfill and were not detected with highly selective sampling procedures. Numerical taxonomy revealed that each monitor holds a unique population which has adapted to that particular milieu. The identification of the isolates, according to Bergey's manual, shows a mixture of water and soil with possibly some refuse organisms - all of which are not primary pathogens but are associated with human disease. Most of the organisms which were identified have at one time or another been involved in human infections. However, the hazards from the landfill are primarily chemical. The microbiological evidence indicates that the aquitard does prevent movement of the particulate material. Cluster analysis has revealed that each monitor and each hydrostratigraphic zone contains a unique population indicating very little, if any, sub soil movement. Sampling in the leachate collection system did reveal one cluster of two strains, one from the trench monitor and one from manhole 4 . This was expected more frequently considering that some mixing may occur.

The study of this land-fill as well as the other sites in Essex County - to be reported - have confirmed the conclusions made on previous studies on bacteria from aquatic econiches, that the predominant population of bacteria is a very sensitive indicator of conditions within that econiche. [Holder-Franklin and Wuest 1983, Holder-Franklin 1986].

There is considerable concern that biodegradation in a sanitary landfill may not be effective. Examination of the physiological activity of bacterial isolates can provide an indication of the degradative capacity. Viable bacteria were counted and isolated from samples of ground water and leachate obtained from several hydrostratigraphic zones within and on the landfill periphery. 
Populations were compared using numerical taxonomy of 63 test responses. Samples were obtained in July, August, September and October from the refuse, the down slope flow line, the brown till, interbedded zone, gray till and periphery including wells 1000, 1500 and 1800 metres away. Each well has a distinctive population by cluster analysis. Wells sampled in July from the leachate and peripheral ground water demonstrated the highest activity related to substrate utilization and fermentation of carbohydrates. These strains also demonstrated physiological versatility being able to grow in a $\mathrm{pH}$ range from 5 to 10 . Aspects of the population examined included substrate utilization, enzyme activity, nitrogen cycling, $\mathrm{pH}$, fermentation of carbohydrates and tolerance to dye and a wide range of $\mathrm{NaCl}$ concentrations. Strains isolated from the leachate included Azomonas insignis, Vibrio nereis, Aeromonas salmonicida and Aeromonas hydrophila as well as Kingella from the July sampling and Enterobacter aerogenes, and Serratia liquefaciens from the September sampling. Pseudomonas cepacia, and $P$. stutzeri were the species which predominated the October sampling. The July samples refected an even mixture of soil and refuse type isolates whereas enteric organisms were the most numerous in the September samples. It must be noted that these samples were from the leachate monitor with a very low population due to the extremely high salt concentration. It was interesting to observe that these organisms had the ability to survive in that environment while their close relatives the Escherichia and Salmonella could not. The biodegradative activity of the aerobic and facultative anaerobic bacteria varies from good to poor in the landfill, and reflects the chemistry.

\subsubsection{Conclusions:}

1. Primary heterotrophic bacterial pathogens were not found in landfill leachate.

2. Potential heterotrophic bacterial pathogens were found in the predominant population.

3. There is little movement of bacterial populations within the site and the surrounding area.

4. The biodegradative capacity varies within the site depending on the environmental conditions.

5. The majority of strains isolated were aerobes or facultative anaerobes, the culture techniques were designed to isolate heterotrophs.

6. The design of landfills does not encourage biodegradation.

7. Studies on the biodegradative potential in waste management are critical to resolving the problem of waste disposal. 


\subsection{Principal Components Analysis of Bacterial Test Responses}

\subsubsection{Introduction:}

The database created by the computation of $369^{2}$ companisons provides a matrix of 136,161 coefficients based on the 63 test responses. Principal components analysis is able to extract the essential variance from the database and present the variance as test related constructs rather than phenotypic clusters. This allows the principal components to be interpreted within the physiological context rather than the taxonomic. However, due to the selection of the database, the interpretations do reflect the taxonomic groups. When the principal components are interpreted biologically, the ecological relevance will emerge. This type of multivariate statistics is not confined to the narrow analysis of a restricted number of variables and extracts the most meaningful sets of variables from the database. In the case of bacteria sequestered in an econiche, the anlysis should reveal the primary environmental influences which have selected that particular population. The dilution methods used to isolate the bacterial strains will select only the predominant population as pure culture isolates. This type of analysis has been used in studies on river bacteria and can be carried foreward to demonstrate causal relationships. The unexpected availability of the chemical data provided a data base that requires considerably more analysis and only the inorganic analysis has been included. Future work will include the organic analysis and the cause and effect study which was very successful in designing the river water I bacterial model. [Holder-Franklin \& Wuest, 1983].

\subsubsection{Methods:}

The test responses of 369 strains isolated from the land fill in July, September and October were analysed using principal components analysis. The database obtained from the NTZ500 output which included 63 nutritional and physiological test responses was analysed by factor analysis using varimax rotation which converged in 7 iterations. Kaiser normalization of 0.7 indicated that the sampling was adequate. The program which was obtained from Statistical Packages for the Social Sciences [SPSS], Nie et al.1992. Principal components analysis computes all of the significant variance in the data. The factors are then interpreted empirically. 


\subsubsection{Results:}

Loadings of each test on each factor indicate the contribution of the test to the factor construct. The interpretation is based on the tests with the highest loadings. The relationship of each factor to the other factors is shown by the calculation of the eigenvalues. Landfill bacterial test responses have been placed in the groups described in Table 8 . The most important physiological group is "fermentative" combined with salt tolerance. The second group are noted by degradation of Kreb's cycle intermediates and compounds defined as generally recalcitrant to degradation. The third group have several of the characteristics of the fluorescent Pseudomonas. The oxidative group does not contribute significantly to the variance itself but two factors can be interpreted as oxidative indicating that the analysis reflects this physiological group. On first perusal, the enteric group contributes very little to the variance, but when combined with the fermentative group of factor 1 we can see the strength of the combination of descriptors. However, it is also surprising that the enteric group has its own factor. The implication is that in addition to a large group of active fermentors, the enteric group has captured enough of the variance to be recognizable. Two Factors selected those organisms which tolerate a wide $\mathrm{pH}$ and although salt tolerance to $10 \% \mathrm{NaCl}$ contributes only $3.1 \%$ of the variance, the bacterial test responses reflect the conditions in the landfill refuse, that of high salt concentrations. The factor was selected by the large number of Enterobacter aerogenes in the cluster. The salt factor is a unique phenomenon in a land fill. Few receive rubble from salt mines. The distortion of the factors was caused by the non-random sampling of the refuse monitor with low counts. The organisms were obtained by enrichment culturing, a highly selective process.

The populations also reflect the mixed sources of bacteria, the fermentative and enteric groups would not be predominant in soil or water and this is the contribution of the waste. On the other hand, the oxidative organism typical of soil are also represented by their physiological profiles. The strong fermentative activity was aslo noted in the feature frequency analysis reported in the previous section. There are many aspects of the test response analysis which have not been explored but are in the process of further mathematical analysis. 


\section{Table 8}

Principal Components Analysis of Test Responses of 369 Bacteria Isolated in 1991 from Landfill \#3.Factor loadings [FL]

\begin{tabular}{|c|c|c|c|}
\hline $\begin{array}{l}\text { Factor } \\
\text { Loading }\end{array}$ & \multicolumn{2}{|l|}{ Factor 1} & Interpretation \\
\hline .777 & \multicolumn{2}{|c|}{ Fermentation(F)of Fructose } & \\
\hline .755 & \multicolumn{2}{|l|}{ (F) Mannitol } & Fermentative/Salt Tolerance \\
\hline .737 & \multicolumn{2}{|l|}{ D-Fructose } & \\
\hline .728 & \multicolumn{2}{|l|}{ (F) fructose } & \\
\hline .721 & \multicolumn{2}{|l|}{ (F) Lactose } & \\
\hline .709 & \multicolumn{2}{|l|}{ Urea } & \\
\hline .679 & \multicolumn{2}{|l|}{ D-Trehalose } & \\
\hline .679 & \multicolumn{2}{|l|}{ D-Glucose } & \\
\hline .673 & \multicolumn{2}{|l|}{$7 \% \mathrm{NaCl}$} & \\
\hline .668 & \multicolumn{2}{|l|}{ D-Cellobiose } & \\
\hline .664 & \multicolumn{2}{|l|}{ D-Ribose } & \\
\hline .637 & \multicolumn{2}{|l|}{ D-Xylose } & \\
\hline .615 & \multicolumn{2}{|c|}{ Glucose Fermentation to $\mathrm{pH} 5.0$} & \\
\hline .570 & \multicolumn{2}{|l|}{$\mathrm{H}_{2} \mathrm{~S}$ Cysteine } & \\
\hline \multicolumn{3}{|c|}{ (oxidase negative loading at 0.4 ) } & \\
\hline$\overline{F L}$ & Factor 2 & \multicolumn{2}{|c|}{ Interpretation } \\
\hline .798 & DL-lactate & \multirow{7}{*}{\multicolumn{2}{|c|}{$\begin{array}{l}\text { Degradation of Kreb's cycle intermediates } \\
\text { and recalcitrant compounds }\end{array}$}} \\
\hline .755 & Pyruvate & & \\
\hline .689 & DL-Malate & & \\
\hline .632 & Putrescine & & \\
\hline .621 & Fumarate & & \\
\hline .511 & DL-Arginine & & \\
\hline-.712 & Starch hydrolysis & & \\
\hline
\end{tabular}




\begin{tabular}{|l|l|l|}
\hline $\begin{array}{l}\text { Table 8 } \\
\text { cont'd. }\end{array}$ & Factor 3 & Interpretation \\
\hline .540 & Laurate & \multirow{2}{*}{ Fluorescent Pseudomonas } \\
\hline .537 & D-Betaine & \\
\hline .643 & L-Leucine & \\
\hline .618 & $0.1 \%$ basic fuchsin & \\
\hline .519 & Denitrification & \\
\hline 509 & Fluorescent piament & \\
\hline
\end{tabular}

\begin{tabular}{|l|l|l|}
\hline \multicolumn{1}{|c|}{ FL } & Factor 4 & Interpretation \\
\hline .739 & O) Sucrose & \multirow{2}{*}{ Oxidative } \\
\hline .738 & (O) Fructose & \\
\hline .720 & (O) Mannitol & \\
\hline .547 & (O) Glucose & \\
\hline .545 & Acetoin Production & \\
\hline .519 & Gelatin liquefaction & \\
\hline$(0)$ - Oxidative Utilization of the sugar & \\
\hline
\end{tabular}

\begin{tabular}{|l|l|l|}
\hline \multicolumn{1}{|c|}{ FL } & Factor 5 & Interpretation \\
\hline .734 & Indole Production & \multirow{2}{*}{ Enteric bacteria } \\
\hline .680 & (F) Sucrose & \\
\hline .675 & Esculin hydrolysis & \\
\hline .667 & Hydroxy-Proline & \\
\hline .635 & D-Arabitol & \\
\hline-.505 & Ornithine decarboxylase & \\
\hline
\end{tabular}




\begin{tabular}{|c|c|c|}
\hline$\overline{F L}$ & Factor 6 & Interpretation \\
\hline .711 & pH 6.8 & $\begin{array}{l}\text { Wide } \mathrm{pH} \text { range - } \\
\text { Nitrate reductase }\end{array}$ \\
\hline .692 & $\mathrm{NO}_{2}-\mathrm{N}_{2}$ Reduction & \\
\hline .679 & $\mathrm{NO}_{3}-\mathrm{NO}_{3}$ Reduction & \\
\hline .639 & $\mathrm{pH} 10.0$ & \\
\hline .594 & $\mathrm{pH} 5.7$ & \\
\hline
\end{tabular}

\begin{tabular}{|l|l|l|}
\hline \multicolumn{1}{|c|}{ FL } & Factor 7 & Interpretation \\
\hline-.614 & $10 \% \mathrm{NaCl}$ & $\begin{array}{l}\text { Sensitive to high concentrations } \\
{[>7 \%] \text { salt }}\end{array}$ \\
\hline
\end{tabular}

Table 9: Summary of factors.

\begin{tabular}{|l|l|l|l|l|}
\hline Factors & Interpretation & $\begin{array}{l}\text { Eigen } \\
\text { Value }\end{array}$ & $\begin{array}{l}\% \\
\text { of } \\
\text { Variance }\end{array}$ & $\begin{array}{l}\text { Cummulative \% } \\
\text { Variance }\end{array}$ \\
\hline Factor 1 & Fermentative salt tolerance & 12.9 & 20.9 & 20.9 \\
\hline Factor 2 & $\begin{array}{l}\text { Degradation of Recalcitrant } \\
\text { Compounds }\end{array}$ & 5.9 & 9.6 & 30.5 \\
\hline Factor 3 & Fluorescent Pseudomonas & 4.1 & 6.6 & 37.0 \\
\hline Factor 4 & oxidative & 3.1 & 5.0 & 42.0 \\
\hline Factor 5 & Enteric bacteria & 2.9 & 4.7 & 41.8 \\
\hline Factor 6 & $\begin{array}{l}\text { Tolerate wide } \\
\text { reduction of } \mathrm{NO}_{3} \mathrm{NO}_{2}\end{array}$ & 2.3 & 3.8 & 50.5 \\
\hline Factor 7 & Salt sensitive @ $>7 \%$ & 1.9 & 3.1 & 53.7 \\
\hline
\end{tabular}




\section{4: Discussion and conclusion:}

The bacterial test responses are now components that are mathematical constructs that can be used in a variety of predictive models. The significance of this analysis will not be apparent until related to the analysis of the chemical and physical data. The principal components of the characteristics of the predominant population of the bacterial flora provide a highly sensitive indicator of the most significant heterotrophic bacterial features operational in the landfill. The fermentative/salt tolerance factor reflects the large cluster obtained from the enrichment procedure and is certainly predictable from the cluster analysis. The analysis is not restricted to the clustered strains as is the feature frequency percentage and does include all the test responses of all of the isolates. However, although sound mathematically, the ecological inference is not as powerful. The remaining descriptors are valid showing the presence of oxidative and nitrate reducing bacteria with some capacity for biodegradation. Bacteria which are not halophiles are salt sensitve and that characteristic varies within the eubacteria, some are highly sensitive and others can tolerate up to $10 \%$. Preservation of food, i.e. prevention of spoilage by the growth of micro-organisms dates back to prehistoric time. With that in mind it is not clear why salt was dumped into the land fill when it is contraindicated by all the biological criteria. 


\subsection{Factor Analysis of Inorganic Chemicals in Landfill \#3}

The chemical analysis of the inorganic chemicals listed in Table 9 was reported by Jagger Hims in 1992. The data was factor analysed using principal axis factoring, oblimin rotation for 9 iterations and tested by Kaiser normalization. The chemical study included $\mathrm{Cl}, \mathrm{SO}_{4}$, alkalinity, $\mathrm{Ca}, \mathrm{CO}_{3}$, $\mathrm{NO}_{3}, \mathrm{NO}_{2}, \mathrm{~F}, \mathrm{Ca}, \mathrm{Mg}, \mathrm{Na}, \mathrm{K}, \mathrm{Fe}, \mathrm{Mn}, \mathrm{Cu}, \mathrm{Zn}, \mathrm{P}, \mathrm{Al}, \mathrm{Ba}, \mathrm{Be}, \mathrm{Bi}, \mathrm{Bo}, \mathrm{Ca}, \mathrm{Cr}, \mathrm{Co}, \mathrm{Pd}, \mathrm{Mb}, \mathrm{Ni}, \mathrm{Ag}, \mathrm{St}$, TK, $\mathrm{Va}, \mathrm{N}$, Phenols and DOC. The organic chemical data is still being analysed for factors, however it should be mentioned here that the volatile organic compounds-toluene, benzene, octachloro-dibenzo p-dioxin, methylene chloride, ethyl benzene, bis (2-ethyl hexal) phthalate, $m$ and $p$-xylene, $p$ and $m$-cresol and dehydroabietic acid were significant in certain monitors.(Jagger Hims, 1992,1994). The list of inorganic chemicals is shown in the factor matrix in Table 11. The organic compounds have not been included in this factor analysis. Loadings on the factors of $>$ 0.5 either in the + or - mode contribute to the construct and can be interpreted .

Table 10: Interpretation of Factors and Their Eigenvalues

\begin{tabular}{|l|l|l|l|l|}
\hline Factor & Eigenvalue & $\begin{array}{l}\% \text { of } \\
\text { Variable }\end{array}$ & $\begin{array}{l}\text { Cummulative } \\
\% \text { Variable }\end{array}$ & Interpretation \\
\hline 1 & 7.19069 & 24.8 & 24.8 & $\begin{array}{l}\text { Reduced nitrogen, } \\
\text { ammonia;barium:low } \mathrm{SO}_{4} \& \mathrm{NO}_{3}\end{array}$ \\
\hline 2 & 4.77868 & 16.5 & 41.3 & Alkalinity; hardness;strontium \\
\hline 3 & 2.82007 & 9.7 & 51.0 & Nutrients,C,N,P \\
\hline 4 & 2.35172 & 8.1 & 59.1 & Salt concentration \\
\hline 5 & 1.18565 & 4.1 & 63.2 & Low pH \&low phosphorous \\
\hline 6 & .88063 & 3.0 & 66.2 & $\mathrm{PO}$ \\
\hline
\end{tabular}

The covariance structure of the database is revealed in factor analysis but the interpretation of the factors is similar to principal components i.e. empirical or based on the logical connection of the descriptors. However, the interpretation is more difficult in some ways because of the database which is simply a list of possible hazards. With this in mind, it is surprising that the factors have a logic which can be interpreted. The most important factor as shown as loadings in table 11 and interpreted in table 10 has a strong nitrogen influence with high loadings for reduced nitrogen and negative loadings for sulfate and nitrate. The presence of ammonia and nitrite indicates that nitrogen is not limiting. The negative loadings for sulfate and nitrate also reflect 
Table 11: Factor Matrix of Inorganic Chemicals

\begin{tabular}{|c|c|c|c|c|c|c|}
\hline Chemical & Factor 1 & Factor 2 & Factor 3 & Factor 4 & Factor 5 & Factor 6 \\
\hline Lab. pH & -.51886 & .38171 & .19192 & .02605 & -.42999 & -.26866 \\
\hline Chloride & .32853 & .60442 & -.28610 & .58867 & -.11939 & .06040 \\
\hline Sulphate & -.70985 & .44711 & .46539 & .15283 & -.14669 & .02327 \\
\hline Alkalinity & -.34211 & .59991 & -.03032 & -.32810 & .10315 & .08909 \\
\hline Nitrate & -.73470 & .18573 & .44705 & .06756 & -.10237 & .14599 \\
\hline Nitrite & .75143 & .05260 & -.38890 & -.24660 & -.24253 & .00999 \\
\hline Ammonia & .41855 & .24338 & .20895 & .28567 & -.25192 & .20410 \\
\hline Calcium & -.01899 & .93341 & -.06343 & -.18716 & .16961 & .12713 \\
\hline Magnesium & -.26909 & .79051 & -.11898 & -.40545 & .14803 & .01879 \\
\hline Hardness & -.13812 & .91044 & -.09266 & -.30510 & .17197 & .08314 \\
\hline Sodium & .25570 & .60942 & -.25785 & .65820 & -.01186 & -.06791 \\
\hline Potassium & .55797 & .02541 & -.13107 & .53792 & -.08858 & .09672 \\
\hline Iron & .59573 & -.27227 & .48847 & -.10076 & .24997 & .01103 \\
\hline Manganese & .62525 & .26402 & .25942 & -.02038 & .19394 & -.12959 \\
\hline Copper & .46195 & .25261 & .56182 & -.21537 & -.25773 & -.18927 \\
\hline Zinc & .45268 & .20133 & .23739 & -.05481 & .26271 & -.02188 \\
\hline Phosphorus & .31579 & .33856 & .33586 & -.43620 & -.48600 & .01551 \\
\hline Aluminum & -.36698 & -.00229 & .23113 & .25475 & -.05381 & .17546 \\
\hline Barium & .81644 & .11259 & .36039 & .02114 & .12526 & -.01423 \\
\hline Boron & .60597 & .18139 & .40831 & .21214 & .16515 & -.03037 \\
\hline Strontium & .25515 & .61782 & -.13575 & .24492 & .23935 & -.10588 \\
\hline Vanadium & -.77902 & .06297 & .51479 & .27599 & .13159 & .02901 \\
\hline Total Nitrogen & .28776 & -.13968 & .60432 & .05181 & .04935 & .10667 \\
\hline Bromine & -.41353 & -.01006 & .08902 & .14448 & .06350 & .37377 \\
\hline Arsenic & -.35173 & -.08431 & .20756 & .24909 & .02095 & .15478 \\
\hline Selenium & -.69675 & -.20623 & .08044 & .07041 & .34581 & -.26848 \\
\hline DOC & .46779 & .03467 & .16578 & .11237 & -.03385 & .15424 \\
\hline Total P & .49704 & -.11874 & .25679 & -.19938 & .11615 & .11023 \\
\hline $\mathrm{PO}_{4}$ & .10625 & -.18881 & -.19601 & -.26786 & .00264 & .56159 \\
\hline
\end{tabular}


microbial activity implying that these compounds are being used as altemate hydrogen acceptors, which is inferred in the principal compnoents analysis of the bacterial database. Factor 2 descriptors - alkalinity, hardness and strontium are linked logically from a geochemical point of view and the relationship with the biological aspects is not apparent. Factors 3 and 6 certainly correlate with some of the bacterial observations.

Within this analysis, the factor correlation matrix, table 12 reveals some significant linkages. Factor 1- nitrogen is linked to the nutrient factor carbon / nitrogen / phosphorus. It is also linked to factor 6 which is interpreted as the phosphate factor. Factor 5 has a high negative correlation with factor 3. Factor 5 - low pH and low phosphorous correlates negatively with all other factors implying a negative influence on the activities in the land fill. This will be revealed when the two datasets, the chemical and biological are correlated. Table 13 indicates the high communalities for chloride,sulfate, sodium, vanadium and hardness. The overview of the nutrient sources for bacteria certainly can be seen from the land fill analysis as possibly carbon limited but this is speculation at this time. Further study will indicate the validity of this supposition.

\subsection{Summary of multivariate statistics:}

1.Salt tolerant, fermentative bacteria dominate the bacterial population according to the principal components analysis. This artificial result was due to the enrichment sampling. Low bacterial counts contradict the factor analysis.

2. A highly active aerobic and facultatively anaerobic population which are metabolically active were observed in leachate and ground water where not inhibited by salt.

3. The enteric bacteria and several species of potentially pathogenic bacteria are significant in the population.

4. Reduced nitrogen levels and low sulfate and nitrate as major variables indicate utilization of these compounds by bacteria in certain monitors.

5. The appearance of the nutrient factor indicated that most samples contained adequate nutrients for bacterial survival.

6. Negative influences for bacteria are shown by the factors - alkalinity, salt concentration, low $\mathrm{pH}$ and low phosphorous 
Table 12: Factor Correlation Matrix

\begin{tabular}{|l|l|l|l|l|l|l|}
\hline Factors & Factor 1 & Factor 2 & Factor 3 & Factor 4 & Factor 5 & Factor 6 \\
\hline Factor 1 & 1.00000 & & & & & \\
\hline Factor 2 & -.02529 & 1.00000 & & & & \\
\hline Factor 3 & .29142 & -.12742 & 1.00000 & & & \\
\hline Factor 4 & .18075 & .09952 & .21166 & 1.00000 & & \\
\hline Factor 5 & -.04520 & -.10386 & -.24890 & -.05628 & 1.00000 & \\
\hline Factor 6 & .18203 & -.20816 & .06860 & -.02632 & 01056 & 1.00000 \\
\hline
\end{tabular}

Table 13: Communality of the Chemical Variables

\begin{tabular}{|l|l|l|l|l|}
\hline Variable & Communality & $*$ & Variable & Communality \\
\hline Lab. pH & .70950 & $*$ & Strontium & .59372 \\
\hline Chloride & .91955 & $*$ & Vanadium & .97018 \\
\hline Sulphate & .96579 & $*$ & Total KJN & .48401 \\
\hline Alkalinity & .60407 & $*$ & Bromine & .34364 \\
\hline Nitrate & .81049 & $*$ & Arsenic & .26035 \\
\hline Nitrite & .83838 & $*$ & Selenium & .73108 \\
\hline Ammonia & .46481 & $*$ & DOC & .28508 \\
\hline Calcium & .95560 & $*$ & Total P & .39248 \\
\hline Magnesium & .89812 & $*$ & POA & .47249 \\
\hline Hardness & .98614 & $*$ & Sodium & .94124 \\
\hline Potassium & .63572 & $*$ & Phosphorus & .75386 \\
\hline Iron & .74039 & $*$ & Aluminum & .28668 \\
\hline Manganese & .58276 & $*$ & Barium & .82547 \\
\hline Copper & .74149 & $*$ & Boron & .64002 \\
\hline Zinc & .37431 & $*$ & & \\
\hline
\end{tabular}




\subsection{Reports and literature cited:}

Balkwill, D. I., J.K. Fredrickson and J.M Thomas, . 1989. Vertical and horizontal variations in the physiological diversity of the aerobic chemoheterotrophic bacterial microflora in the deep southeast coastal plain subsurface sediments. Appl. Environ. Microbiol. 55: 1058-1065

Balows,A.,H.G. Truper, M. Dworkin, W. Harder,K-H.Schleifer(eds.)1992. The Procaryotes: A Hand book on the Biology of Bacteria: Ecophysiology, Isolation, Identification, Applications. second edition.Springer Veriag New York Berlin Heidelberg London Paris Tokyo HongKong Barcelona Budapest. ISBN 0-387-29258-7. 4 vols.

Barlaz,M.A., D.M. Schaefer and R.K. Ham.1989. Bacterial population developement and chemical characterization of refuse decomposition in a simulated sanitary landfill. Appl.Environ.Microbiol. 55:55-65.

Barlaz, M.A., R.K. Ham and D.M. Schaefer. 1992. Microbial, chemical and methane production of anaerobically decomposed refuse with and with out leachate recycling.58:

Colby,J.,H. Dalton and R.Whittenbury.1979. Biological and biochemical aspects of microbial growth on C1 compounds. Ann. Rev. Microbiol.33:481-517.

Cormier, C.J. and Holder-Franklin, M.A. 1981. Seasonal and diumal changes in the predominant heterotrophic bacterial species of the Meduxnekeag River. Holder-Franklin, M.A. In: D.B. Carlisle(ed.), Methods of studying population shifts in aquatic bacteria in response to environmental change. Inland Waters Direct.Sci. Ser. 124: 43-77.

Desaulniers, D.E., Cherry, J.A. and Fritz, P. 1981. Origin, age and movement of pore water in argillaceous quatemary deposits at four sites in South Westem Ontario. J. Hydrol. 50: 231-257.

Georges,S. 1995. Application of Microbiological, Hydrogeological, and Genetic Methods for Detection of Ground Water Movement. M.Sc. Thesis, University of Windsor.

Hoeks,J. 1983. Significance of biogas production in waste tips. Waste Management and Research. 1:323-335.

Holder-Franklin, M.A. 1981. Methods of studying population shifts in aquatic bacteria in response to environmental change. D.B. Carlisle (ed.), Inland Waters Direct.Sci. Ser. 124. Ottawa.

Holder-Franklin, M.A., Thorpe, A. and Cormier, C.J. 1981. Comparison of numerical taxonomy and DNA-DNA hybridization in diumal studies of niver bacteria. Can. J. Microbiol. 27:1165-1184. 
Holder-Franklin,M.A. and L.J. Wuest. 1983. Population dynamics of aquatic bacteria in relation to environmental change as measured by factor analysis. J.Microbiol. Meth.1:209-227.

Holder-Franklin, M.A. 1986. Ecological relationships of microbiota in water and soil as revealed by diversity measurements. in R.L. Tate,III, ed. Microbial Ecology: A method for environmental studies. John Wiley \& Sons, Inc.

Holder-Franklin, M.A., Favrin, K., Sklash, M., Chaisson, A. and Georges, S. 1991. Resistance to lead and cadmium in groundwater bacteria. Abstract, Can. Soc. Microbiol. Annu. Meet. EM 8P. Holder-Franklin, M.A., Thorpe, A. and Wuest, L. 1992. Evaluation of tests employed in the numerical taxomony of river bacteria. J. Microbiol. Methods 15: 263-277.

Holder-Franklin, M.A. 1992. Aquatic microorganisms: processes, populations, and molecular solutions to environmental problems. J. Aquatic. Ecosys. Health. 1: 31- 40.

Ibrahim, O. 1992. Groundwater recharge investigation of a Linear morphological feature east of Belle River, Ontario. M.Sc. thesis, University of Windsor, Windsor, Ontario.

Jagger Hims Ltd. Environmental Consulting Engineers. 1992. Essex County Landfill No.3, 199I Annual Monitoring Program Report.

Jagger Hims Ltd. Environmental Consulting Engineers. 1993. Essex County Landfill No.3, 1992 Annual Monitoring Program Report.

Jagger Hims Ltd. Environmental Consulting Engineers, 1994. Essex County Landfill No. 3, 1993 Annual Monitoring Program Report.

Krieg, N.R. and Holt, J.G. 1984. Bergey's Manual of Systematic Bacteriology. Vol. 1. Williams and Wilkins. Baltimore.

Sklash, M.G., Ibrahim, O.A. 1991. Grant 389; Hydrogeological implications of burried eskers in Essex County, Ontario: results from year 1. In: Geoscience Reasearch Program, Summary of Research 1990-1991, V.G. Milne (ed.), Ont. Geol. Surv. Misc. Paper. 156: 131-145.

Sklash, M.G., and Ainslie, A.M. 1991. The use of environmental isotope surveys in essessing contamination potential of confined aquifers. In Proceedings. Vol. II. Toronto, Ontario.

Sneath, P.H.A. 1957a. Some thoughts on bacterial classification. J. Gen. Microbiol. 17: 184-200.

Wuest, L. J. 1981. Numerical analysis. Holder-Franklin, M.A. In: D.B. Carlisle (ed), Methods of studying population shifts in aquatic bacteria in response to environmental change. Inland Waters Direct.Sci. Ser. 124: 12-15. 
